\title{
Por um Epílogo para a Anulação como Resultado de Recursos Cíveis - a Ampliação do Julgamento Imediato do Mérito e da Correção de Vícios no Tribunal
}

\author{
Per un Epilogo per il Annullamento come Risultato delle Impugnazioni Civili - Ampliamento \\ del Giudizio Immediato di Merito e Correzione dei Vizi in Tribunale
}

Lucas Buril de Macêdo'

${ }^{1}$ Universidade Federal de Pernambuco - UFPE, Brasil

\begin{abstract}
Riassunto
Ao abordar a diferenciação entre errores in procedendo e in judicando, este trabalho pesquisa sobre a atenuação da anulação de decisões judiciais com remessa para o juízo a quo como resultado do recurso. Percebe-se que a previsão de julgamento imediato do mérito impactou significativamente no assunto, até mesmo dando margem à caracterização do duplo grau de jurisdição no direito brasileiro. Mais além, percebe-se que o CPC/2015 contém regras de saneamento recursal e de produção de provas nos recursos, que, caso interpretadas de modo ampliativo, podem potencializar o julgamento imediato do mérito. O trabalho perpassa por esses institutos para realizar essa construção.
\end{abstract}

Palavras-chave: Recursos; Error in procedendo; Anulação; Julgamento imediato do mérito; Correção de vícios

\begin{abstract}
Nell'affrontare la differenziazione tra errores in procedendo e in judicando, questo lavoro indaga sulla mitigazione dell'annullamento delle decisioni giudiziarie con rinvio del processo come conseguenza del ricorso. $\grave{E}$ chiaro che la disposizione per un giudizio immediato sul merito ha avuto un impatto significativo sulla questione, anche modificando la caratterizzazione del doppio grado di giurisdizione nella legge brasiliana. Inoltre, il c.p.c. brasiliano di 2015 contiene regole per correzione delle vizi processuali nel procedimento del mezzo di impugnazione e che permettono la produzione di prove, che, se interpretate in senso ampio, possono ingrandire l'immediato giudizio di merito. Il lavoro passa attraverso questi istituti per realizzare questa costruzione.
\end{abstract}

Parole Chiave: Mezzi di impugnazione; Error in procedendo; Annullamento; Giudizio immediato del merito; Correzione dei vizi.

\section{Introdução}

Na história do direito processual, os recursos vêm sofrendo constantes alterações. Algumas mudanças são mais significativas e marcam a história do processo, como aquele momento histórico no qual, dando força ao princípio dispositivo, a reforma para pior passou a ser proibida. Outras revelam sua importância na práxis e para o direito interno, como as sucessivas mudanças no agravo de instrumento ocorridas durante a vigência do Código de Processo Civil de 1973 e com a chegada do Código de $2015 .{ }^{1}$

1 Vale lembrar a aguda crítica: "Acredito que os usuários da função jurisdicional (não seus beneficiários, que têm lucrado com o caos) já nenhuma dúvida tenham de que reformar, deformar, reconformar o agravo leva a alguma coisa. Bem como lugar nenhum leva o transitar a tutela jurídica deste para aquele momento do procedimento, ou carregar o céu processual com ameaça de mil raios mortais de multas, sanções, constrições e contorções imponíveis aos litigantes, sempre se preservando os magistrados em relação aos jurisdicionados para compensar sua antidemocrática subordinação 
De fato, o sistema recursal tem desempenhado papel de protagonista nas várias reformas de lei processual, assim como teve papel de relevância na própria mudança de Código de Processo. ${ }^{2}$ As razões disso são evidentes: há intenso descontentamento com a eficiência e racionalidade dos recursos cíveis, aprimorando-se tanto quanto possível as normas regulamentadoras do direito recursal, de modo que se alcance melhoras na performance dos recursos. ${ }^{3}$

Este texto se insere nesse contexto, e examina especificamente a abordagem dos errores in procedendo nos recursos cíveis e as suas consequências no processo civil. Tradicionalmente, recurso que demonstre ter ocorrido erro de procedimento enseja a anulação da decisão ou de parte do processo, com o desfazimento dos atos nulos e os subsequentes, e a remessa do processo de volta para o juízo $a$ quo, a fim de que os atos anulados sejam refeitos e o procedimento retomado para a prolação de nova decisão.

Pretende-se demonstrar como essa configuração do sistema recursal tem sido objeto de paulatinas mudanças, bem como demonstrar que existem razões imperativas a determinar a continuidade dessas transformações, de modo que se desenhe verdadeiro epílogo para a anulação de decisões judiciais como resultado de recursos cíveis. Este texto, portanto, empreende exame crítico com o propósito de recomendar, de lege ferenda, a continuidade do movimento que se encontra em curso no direito positivo brasileiro.

\section{Os Vícios das Decisões Judiciais}

\subsection{Noções históricas e conceituais}

Historicamente, o precursor de todos os recursos, a appellatio, não servia à discussão de nulidades processuais e nem poderia ensejar a anulação do processo. O recurso era próprio para a discussão de injustiças. Nulidades ensejariam algo mais próximo à inexistência, de modo que seria possível ação declaratória para afastar o processo nulo e seus efeitos.

A apelação ligava-se à renovação do curso da mesma causa e, mais do que ao direito à correção de erros, ao direito a uma nova decisão de mérito. ${ }^{4}$ Isso é algo que fica mais claro ao se observar a sua raiz histórica: no direito romano pós-clássico, no medievo e até mesmo nas Ordenações, a apelação, que era o recurso por excelência, impugnava apenas a injustiça da sentença, isto é, os errores in judicando. As invalidades processuais, causadas por errores in procedendo, tornavam nula a sentença - vício este que tinha um significado específico, mais ligado à inexistência, como concebida hoje -, que poderia ser

aos tribunais" (CALMON DE PASSOS, José Joaquim. As razões da crise de nosso sistema recursal. Meios de impugnação ao julgado civil - Estudos em homenagem a José Carlos Barbosa Moreira. Adroaldo Furtado Fabrício (coord.). Rio de Janeiro: Forense, 2007, p. 375).

2 Sobre isso, vale a interessante passagem: "Na época em que entrou em vigor o Código de Processo Civil de 1973, o sistema de recursos por ele instituído foi considerado um dos seus aspectos positivos, pela sensível simplificação que representou em relação ao regime anterior. Basta dizer que na vigência do Código de 39 havia nada menos que três recursos diferentes contra as decisões interlocutórias (o agravo de instrumento, o agravo no auto do processo e a carta testemunhável), cuja admissibilidade variava por critérios bastante casuísticos, bem como dois recursos diferentes contra a sentença de primeiro grau (a apelação e o agravo de petição). Não obstante esse avanço, decorridas quatro décadas de vigência do Código de 1973 e após incontáveis alterações, o seu sistema de recursos é apontado por muitos como o grande responsável pela crise da Justiça brasileira, conforme se manifestou a Comissão de Constituição e Justiça do Senado Federal, ao analisar a Proposta de Emenda à Constituição que deu origem à Emenda Constitucional 45/2004" (GRECO, Leonardo. Instituições de processo civil. Rio de Janeiro: Forense, 2015, v. III, p. 1).

3 Há quem pense serem os próprios recursos fruto de um problema: "É verdade também que os recursos, sendo como são, a expressão da desconfiança com que o sistema político herdado da Revolução Francesa via a magistratura, representam um instrumento que exacerba o sentido burocrático da jurisdição, com a consequente perda de legitimidade da jurisdição de primeiro grau" (SILVA, Ovídio A. Baptista da. Curso de processo civil. 7ํㅡ ed. Rio de Janeiro: Forense, 2006, p. 389).

4 CALAMANDREI, Piero. Appello. Opere giuridiche. Napoli: Morano, 1979, v. VIII, p. 445. 
atacada a qualquer tempo, no direito comum, pela chamada querela nullitatis. ${ }^{5}$ Nessa época, portanto, era importantíssimo diferenciar os vícios da sentença: se de injustiça ou mérito, ou se de legalidade ou processo. ${ }^{6}$ Essa diferença impactava diretamente no meio para atacá-la: o apelo ou a impugnação para reconhecimento de nulidade, respectivamente. É só modernamente que o apelo vem a se tornar o remédio para atacar as sentenças injustas e nulas. ${ }^{7}$

Essa realidade é alterada e o recurso de apelação passa a absorver a ação de nulidade, concentrando os meios de impugnação da sentença. Essa mudança tornou a apelação o meio genérico de impugnação, podendo servir para reformar a sentença ou para anulá-la, isto é, veicula tanto os errores in judicando como os errores in procedendo. Ambos os vícios passam a ser arguíveis no recurso.

Nos sistemas jurídicos contemporâneos, quase todos os vícios que tornam a sentença nula foram absorvidos como causas para sua impugnação por recurso, em vez de servirem eficazmente como uma causa para uma ação de nulidade. ${ }^{8}$ Com a evolução do direito processual e o avanço e melhor estruturação do direito recursal, as ações de declaração (ou decretação) de nulidade tornaram-se demandas recursais. ${ }^{9}$

O error in procedendo é, portanto, uma possível causa de pedir dos recursos.

A causa petendi é o elemento justificador da demanda: é composta pela parcela do arrazoado da parte que é juridicamente relevante para revelar o porquê daquele pleito. Todavia, especificar precisamente quais os elementos das razões das partes que ingressam na causa de pedir - isto é, que são juridicamente relevantes para caracterizar a demanda - é um sério problema teórico, que já recebeu várias respostas ao longo da história e de acordo com diferentes linhas de pensamento. Certamente a causa de pedir é o mais difícil elemento de se definir para o objeto do processo. ${ }^{10}$

5 "Sententia nulla in origine equivale a sentenza inesistente (nec ulla sententia) e così radicalmente inefficace e, come tale, suscettibile di venire accertata in ogni momento ed in qualunque sede giudiziale od extragiudiziale, senza che all'inizio fosse, a tal riguardo, predisposto alcun rimedio specifico. Successivamente, emerse uno strumento, quello della actio nullitatis sententiae, azione, in origine di primo grado, che, in seguito, per ragioni di certezza dei rapporti giuridici, venne assoggettata (dalle legislazioni statutarie dei comuni italiani) ad un termine seppur lungo per quasi tutte le nullità, rese così suscettibili di sanatoria: è questa la fase storica della c.d. querela nullitatis, ormai impugnazione anch'essa, ma riservata alle invalidità dovute a violazioni di norme processuali” (CONSOLO, Claudio. Le impugnazioni delle sentenze e dei lodi. 3ª ed. Milano: CEDAM, 2012, c. 1, item 2.2 - versão digital).

6 Essa divisão, no entanto, recebeu importantíssima crítica, à qual se adere: "Ma vi è una ragione molto più profonda ed importante, che induce al rigetto della riferita costruzione teorica. Al di sotto di essa, invero, circola l'idea, più o meno esplicitamente espressa, che possa darsi una sentenza giusta nel contenuto (quindi sostanzialmente conforme al diritto) anche se viziata processualmente, quindi nulla. Riappare così la scissione, da noi sempre avversata, tra diritto sostanziale e processo strumentalmente inteso, figlia della angusta ed insufficiente concezione normativistica del diritto, per cui la giustizia della sentenza sarebbe qualcosa di avulso e staccato dal processo giurisdizionale, che ha condotto alla sua emanazione. Anche se la legge del processo venga violata, infine e ciò malgrado il giudizio può essere nella sostanza giuridicamente corretto; da qui breve è il passo per l'ulteriore illazione: si può giungere alla 'giustizia' indipendentemente dalla regolarità formale del processo".

"Detto questo, basta davvero poco per dimostrare tutta la erroneità e pericolosità della esposta concezione, poiché, come costantemente avvertito, non è assolutamente lecito né possibile astrarre le sentenze dal modo, in cui si perviene alla loro formazione ed emanazione. La sentenza è egualmente ingiusta e viziata tanto se venga violata la norma processuale, quanto se venga violata la norma sostanziale, e ciò non tanto e non solo perché la violazione della prima costituirebbe un sintomo della eventuale violazione anche della seconda, ma per la più essenziale ragione che al di fuori della legge del processo non esiste un giudizio, ma un atto di arbitrio, e l'arbitrio, qualunque sia il suo contenuto sostanziale, è la massima espressione dell'ingiustizia” (MONTELEONE, Girolamo. Diritto processuale civile. 8ª ed. Milano: CEDAM, 2018, volume II, p. 568).

7 LIEBMAN, Enrico Tullio. Appunti sulle impugnazioni. Milano: La Goliardica, 1959, p. 2-3. Ver, sobre essa transformação: CONSOLO, Claudio. Le impugnazioni delle sentenze e dei lodi. 3aㅡ ed. Milano: CEDAM, versão digital, c. 1, item 2.3.

8 BARBOSA MOREIRA, José Carlos. Comentários ao Código de Processo Civil. 16 $6^{\mathrm{a}}$ ed. Rio de Janeiro: Forense, volume V, p. 230-232.

9 “A apelação do direito brasileiro contém a impugnativa da injustiça e a querela de nulidade, apagada, afinal, a distinção romana entre meio contra a injustiça e impugnabilidade, sem prazo, da inexistência" (PONTES DE MIRANDA, Francisco Cavalcanti. Comentários ao Código de Processo Civil. 3ㅜㅡㄹ. ed. Rio de Janeiro: Forense, 1999, tomo VII, p. 154).

10 "Hoje é tarefa praticamente impossível emitir um conceito unívoco e abrangente de causa de pedir" (TUCCI, José Rogério Cruz e. A causa petendi no processo civil. $3^{3}$ ed. São Paulo: RT, 2009, p. 26). Para uma análise das várias ideias sobre o tema, conferir o mesmo autor e mesma obra, p. 78-91 e p. 95-109. 
Causa de pedir é elemento de forte contato com o direito material - inclusive, já se defendeu que seu conteúdo assume puramente a relação jurídica de direito material, ideia superada. ${ }^{11}$ Realmente, a causa de pedir é composta pela afirmação da relação jurídica material e dos fatos jurídicos que a geraram. O demandante, ao pedir a tutela jurisdicional, deve justificar o provimento requerido com base no ordenamento jurídico, deduzindo os fatos jurídicos e a decorrente relação jurídica que autoriza a sua prolação. Causa de pedir, portanto, é a base jurídica para o pedido, o título que o legitima; é o que, caso efetivamente constatado, autoriza o exercício do poder jurisdicional, nos moldes como pleiteado.

No recurso, ${ }^{12}$ deduz-se pretensão recursal, ${ }^{13}$ de modo que se pode delinear objeto próprio para a relação recursal. ${ }^{14}$

A demanda recursal é composta pela causa de recorrer e o pedido recursal. A causa de recorrer são as razões apontadas pelo recorrente para que seja realizada a reforma ou anulação do ato decisório impugnado. Assim, a causa petendi recursal é identificada no error in procedendo ou error in iudicando que motivam a interposição do recurso. ${ }^{15} \mathrm{O}$ pedido recursal é a tutela jurisdicional específica pedida, normalmente limitada ao proferimento de decisão com conteúdo diverso, substituindo a decisão impugnada, ou a anulação da decisão proferida, com determinação ao órgão prolator da decisão recorrida que profira nova decisão. ${ }^{16}$ A finalidade a que se propõe o recurso, corporificada em seu pedido, é a de corrigir ou eliminar a decisão judicial, excluindo os seus efeitos negativos sobre a parte recorrente. ${ }^{17} \_18$

$11 \quad$ Apenas para que fique claro: nem sempre o objeto do processo será composto por uma relação jurídica de direito material - entendido aqui em contraposição com o direito processual. Na ação rescisória, por exemplo, o objeto pode ser a competência absoluta do juízo que prolatou a decisão rescindenda. Noutro exemplo, o mandado de segurança contra ato judicial pode ter como objeto o direito à publicidade restrita de um processo, que tenha sido indeferida pelo juiz. Nestes casos, assim como em tantos outros, o mérito é inequivocamente uma questão de direito processual. Não se pode afirmar, portanto, ao menos não com correção geral, que o objeto do processo é uma relação jurídica substancial, mas, sim, um "direito litigioso" (cf. ASSIS, Araken. Cumulação de açôes. 4ª ed. São Paulo: RT, 2002, p. 49). De todo modo, apenas para simplificar a exposição, será assumida a situação que normalmente acontece: o mérito como uma relação jurídica de direito substancial.

12 "A palavra origina-se do latim - recursus - que contém a ideia de voltar atrás, de retroagir, de curso ao contrário. O vocábulo primitivo compunha-se da partícula iterativa re, de origem ignorada, anteposta ao substantivo cursus, proveniente do verbo currere" (LIMA, Alcides de Mendonça. Introdução aos recursos cíveis. $2^{a}$ ed. São Paulo: RT, 1976, p. 123). Sobre a origem e os usos da palavra: MONTEIRO, João. Teoria do processo civil. $6^{\mathrm{a}}$ ed. (atualizado por J M de Carvalho Santos). Rio de Janeiro: Borsoi, 1956, p. 604-605.

13 PONTES DE MIRANDA, Francisco Cavalcanti. Comentários ao Código de Processo Civil, VII, cit., p. 1.

14 Amplamente: MACÊDO, Lucas Buril de. Objeto dos recursos cíveis. Salvador: Juspodivm, 2019.

15 "I difetti che possono viziare una sentenza sono di due specie: vizi di giudizio (errores in iudicando) e vizi di attività (errores in procedendo). I primi riguardano il giudizio pronunciato dal giudice sulla esistenza dell'azione e sulla sua fondatezza, e si distinguono a loro volta in errori di fatto e in errori di diritto, a seconda che il giudice abbia accertato il fatto in modo disforme dal vero, od abbia errato nel valutare giuridicamente il fatto e nell'applicare ad esso il diritto; essi hanno per conseguenza l'ingiustizia della sentenza. I secondi sono errori commessi dal giudice nel compiere le attività del suo ufficio nel corso del procedimento o nel pronunciare sulla legalità e regolarità degli atti suoi e di quelli delle parti, e producono la nullità della sentenza; e comprendono tra l'altro gli errori in cui il giudice può essere incorso nel pronunciare sui presupposti processuali, o nel non aver rilevato la loro mancanza, le nullità non sanate verificatesi nel corso del processo e il difetto delle condizioni di validità della stessa sentenza" (LIEBMAN, Enrico Tullio. Appunti sulle impugnazioni. Milano: La Goliardica, 1959, p. 2).

16 Embora a doutrina costume usar a fórmula "reformar, anular, integrar ou esclarecer", sobretudo diante da conceituação de recurso de BARBOSA MoREIRA, parece que integrar e esclarecer são mecanismos de reforma da decisão, ainda que para manter seu conteúdo inalterado. Isto é, modifica-se a sentença como "ato formal", acrescentando ou alterando o seu texto, embora ela seja mantida em seu sentido. Há reforma do conteúdo da sentença com preservação de seu sentido, pelo que parece desnecessário o acréscimo de "integrar" e "esclarecer" aos possíveis pedidos recursais. São, bem vistas as coisas, tipos especiais de reforma.

17 MONTELEONE, Girolamo. Diritto processuale civile. $8^{\mathrm{a}}$ ed. Milano: CEDAM, 2018, volume IIํㅜ p. 566.

18 Não se deve confundir o objeto do recurso, entendido como o que deve ser decidido em sede recursal, com a finalidade. Confunde-se, assim, afirmando ser objeto do recurso a realização da justiça: PODETTI, J. Ramiro. Tratado de los recursos, cit., p. 17 
Enfim, o error in procedendo serve como causa de pedir recursal para basear o pedido de anulação da decisão judicial impugnada.

\subsection{Error in procedendo e error in iudicando}

Os ilícitos cometidos na decisão são tradicionalmente classificados como error in judicando ou error in procedendo. O primeiro é visto como uma injustiça no julgamento e o segundo como um erro na condução do procedimento.

Tradicionalmente, diferencia-se um do outro de acordo com a norma jurídica que seria aplicável e foi alegadamente transgredida. O error in judicando seria erro na aplicação de norma jurídica de direito substancial, enquanto, por sua vez, o error in procedendo seria o erro na aplicação de norma de direito processual. Nesse sentido, Giuseppe Chiovenda falava de vício de atividade como o erro na aplicação do direito processual, e vício de juízo como erro na aplicação do direito material. ${ }^{19}$

O error in procedendo pode ser um erro de procedimento, como é classicamente compreendido, no sentido de um equívoco do juízo na condução do processo - como, p. ex., falta de intimação da parte para se manifestar sobre documento, negativa de produção de prova, condução do processo com defeito na representação das partes. Pode ser também que o erro se dê na aplicação de normas processuais, que, embora não se relacionem com o procedimento, também não se confundem com a noção de error in judicando, pois não compõem, propriamente, a matéria decidida, como nos casos de vício de congruência e de obscuridade ou contradição na motivação, entre outros. Essa segunda espécie de error in procedendo é classificada como erros de atividade. ${ }^{20}$

Os errores in judicando, por sua vez, são equívocos de conteúdo na decisão: ao apreciar os fatos relevantes ou ponderar acerca da aplicação normativa, ocorreu a assunção de uma falsa premissa ou houve uma falha na formulação de conclusões. O erro de julgamento torna o próprio conteúdo da decisão contrário ao direito (ilícito). ${ }^{21}$

Nesse sentido, Piero Calamandrei expõe que o error in judicando conduz a uma declaração errônea da lei, mas pode inquinar de vício a própria jurisprudência, isto é, o meio prático a partir do qual o direito objetivo evolui e se aperfeiçoa. ${ }^{22}$

Também há erro de julgamento quando se soluciona erradamente uma quaestio facti.

A revisão de questões fáticas merece enquadramento adequado. No ponto, Calmon de Passos parte do pressuposto de que seria possível o uso de apelação por mera inconformidade da parte com a versão fática adotada na sentença. Por conta disso, sugere alteração no recurso de apelação: "nesse recurso não se pode pleitear o reexame da matéria de fato, no tocante à sua valoração para fins de convencimento do julgador, sendo controlável, entretanto, seus erros de procedimento na realização da prova ou seus erros de julgamento no tocante aos fatos com vistas à fundamentação por ele oferecida, entendida esta como rigorosamente adstrita à prova dos autos". ${ }^{23}$

19 CHIOVENDA, Giuseppe. Principii di diritto processuale civile. $3^{3}$ ed. Napoli : Jovene, 1923, p. 1023-1030.

20 FAIRÉN GUILLÉN, Víctor. Estudios de derecho procesal. Madrid: Editorial Revista de Derecho Privado, 1955, p. 340-

344.

21 Em interessantíssimo trabalho, Calamandrei examina a teoria do processualista alemão Beling, segundo o qual todo erro cometido pelo julgador é necessariamente in procedendo, uma vez que ele apenas seria destinatário de normas processuais - os destinatários das normas civis são as partes, logo, são elas que descumpririam tais normas. Calamandrei, reconhece parcialmente a correção da ideia, mas prossegue para diferenciar os errores in judicando como aqueles que, embora decorram da falha da conduta do juiz de, no processo, julgar conforme o direito, fazem a vontade do Estado-juiz, ao julgar o caso, diferir da vontade concreta da lei. Conclui, então, que o error in judicando é dúplice, pois, além de conter um erro processual, erra também no reconhecimento da vontade concreta da lei. Com muito proveito, conferir: CALAMANDREI, Piero. Sulla distinzione tra error in judicando ed error in procedendo. Opere giuridiche. Napoli: Morano, 1979, v. VIII, p. $285-291$.

22 CALAMANDREI, Piero. Sulla distinzione tra error in judicando ed error in procedendo, cit., p. 294.

23 CALMON DE PASSOS, José Joaquim. As razões da crise de nosso sistema recursal, cit., p. 377. 
No entanto, não se verifica essa possibilidade de livre recorribilidade, como se fosse possível impugnar uma decisão por desgostar dela ou pelo incômodo que causa. Não. O mecanismo de controle é jurídico, o que o insere numa cadeia de aplicação do Direito. Não se vislumbra sua utilização fora do padrão que deve nortear todo o processo: a juridicidade. A impugnação aos errores in judicando que se relacionem à esfera fática se dá, também, pela ilicitude da sentença. É admissível, apenas, o recurso que se queixa de uma ilegalidade: justamente como observou o mestre baiano, seja no equívoco de aplicação das normas de prova ou de convencimento. A impugnação contra a decisão que deixa de apontar qualquer ilicitude no seu conteúdo é inadmissível por falta de dialeticidade: não demonstrou motivos específicos para a reforma da decisão.

No caso dos erros fáticos, portanto, cumpre ao recorrente demonstrar que a conclusão adotada não tem sustento no conjunto probatório, tendo o magistrado descumprido o seu dever de julgar de acordo com a prova dos autos. Não pode o recorrente limitar-se a queixar-se da reconstrução fática empreendida pelo julgador ou genericamente acusá-la de errônea: ele tem o ônus de especificar as razões da censura e indicar qual a correta representação histórica que decorre dos meios de prova produzidos no processo, explicando e ilustrando as causas e consequências das provas nos juízos fáticos e destes nas conclusões da decisão. ${ }^{24} \mathrm{O}$ recurso que impugna uma quaestio facti, portanto, submete a conclusão fática da decisão impugnada a um procedimento de "falseamento", no qual é ônus do recorrente demonstrar o vício na reconstrução dos fatos feita na decisão recorrida, oferecendo uma hipótese conclusiva diversa. O recurso assume a posição de um instrumento epistemológico para controle da hipótese fática assumida pelo primeiro julgador. ${ }^{25}$

Note-se que, nesse particular, o apelo cumpre um importante papel de controle racional do juízo fático, especialmente nos casos em que o juízo anterior teve contato direto com as provas, servindo o recurso como mecanismo de racionalização da valoração das provas, excluindo das inferências realizadas eventuais características irrelevantes para a conclusão fática. No recurso, a distância física e temporal entre o seu órgão julgador e a produção de provas permite que seja depurada a resolução fática, excluindo a relevância de elementos de ordem emocional ou subjetiva que porventura tenham ingressado na tomada de decisão. ${ }^{26}$

São necessárias algumas reflexões sobre a tradicional relação entre a natureza da norma aplicável - se de direito substancial ou de direito processual - e a qualidade do erro imputável à decisão.

Não necessariamente o error in judicando é equívoco na aplicação do direito material. Embora o erro procedimental seja sempre de aplicação do direito processual, o contrário não é verdadeiro: o erro no conteúdo do ato decisório pode ser de direito processual. ${ }^{27}$ Além do evidente exemplo de decisões interlocutórias que resolvem questões de processo - e.g., as que versam sobre dinamização do ônus da prova, caso em que ocorrerá erro de julgamento sujeito a reforma por agravo de instrumento (art. 1.015, XI, do CPC), se houver redistribuição em caso que não é cabível. ${ }^{28} \mathrm{~A}$ fixação incorreta de honorários em

24 "Se le censure attengono alla quaestio facti, all'appellante si fa onere di esporre specifiche critiche alla pronuncia resa in prime cure e di proporre al secondo giudice una diversa ricostruzione dei fatti, in base alle prove acquisite o delle quali chieda l'assunzione o la rinnovazione in appello, entro i limiti dei mezzi di prova già dedotti o di quelli acquisibili anche d'ufficio o di quelli proponibili e producibili in base alla disciplina delle nuove prove in appello, anch'essa oggetto delle improvvide modifiche di cui infra diremo" (TEODOLDI, Alberto. I motivi specifici e le nuove prove in appello dopo la novella 'iconoclastica' del 2012. Rivista di diritto processuale. Padova: CEDAM, v. LXVIII, n. 1, 2013, p. 148).

25 TEODOLDI, Alberto. L'appello civile. Torino: Giappichelli, 2016, p. 20-24.

26 TEODOLDI, Alberto. L'appello civile, cit., 22-23. Conclui o processualista: "La riesaminabilità in appello del giudizio di fatto costituisce, dunque, garanzia di autentica razionalità giudiziaria, che vuol sottoposto al fuoco delle lagnanze appellatorie l'accertamento dei fatti di causa. Detta riesaminabilità è la proiezione e lo sviluppo successivo della regola del contradditorio quale metodo autenticamente isonomico di controllo della prova, nei suoi esiti non meno che nel suo formarsi coram iudice. La possibilità di censurare il giudizio di fatto espresso dal giudicante per la prima volta con la pronuncia della sentenza garantisce le parti contro il rischio di decisioni avulse dal contesto dei fatti accertati o emesse addirittura in assenza di istruttoria veruna, consentendo il pieno esercizio del diritto di critica verso le pronunce giudiciali, onde far sgorgare l'accertamento fattuale mercé il confronto fra diverse ipotesi ricostruttive dei fatti storici” (p. 23).

27 CALAMANDREI, Piero. Sulla distinzione tra error in judicando ed error in procedendo, cit., p. 295-296.

28 Sobre o tema, já se escreveu em outra oportunidade: MACÊDO, Lucas Buril de; PEIXOTO, Ravi Medeiros. Ônus da prova e sua dinamização. $2^{a}$ ed. Salvador: Juspodivm, 2016. 
sentença, outro exemplo, é aplicação de norma processual que enseja erro de julgamento. É possível que o julgador erre não na condução do procedimento em si ou no respeito às formalidades do processo, mas na aplicação da norma de processo no conteúdo de sua decisão, quando mal perceber o suporte fático ou sua hipótese fática ou der-lhe consequências inadequadas, configurando-se error in iudicando sujeito a reforma.

Percebe-se que o erro de julgamento é erro de aplicação do direito no conteúdo da decisão, que pode versar tanto sobre direito material quanto sobre direito processual. ${ }^{29}$ Aliás, pode-se ir mais além: todo erro processual supõe um erro de julgamento, em alguma medida.

Para explicar isso é válido um exemplo.

Na condução de processo, o juiz indefere a produção de prova testemunhal. Trata-se de questão afeta à admissibilidade da produção de prova, matéria inequivocamente de direito processual. A decisão que indefere a prova testemunhal examina a sua admissibilidade no caso. Por exemplo, o juiz pode chegar à conclusão de que a prova testemunhal não é admissível porque se trata de fato já provado por documento (art. 443, I, CPC). Ao assim fazer, pode ser que cometa erro de juizo, aplicando o dispositivo em hipótese na qual não é aplicável (por exemplo, porque não há prova documental sobre o fato que se quer provar). Não há dúvidas de que se trata de aplicação de direito processual, da mesma forma que é muito claro que ocorre um error in judicando, compreendido como erro no conteúdo do ato decisório.

Ora, se o error in judicando é um erro na aplicação do ordenamento jurídico, não há dúvida de que, ao conduzir o processo, o juiz o faz com base no sistema processual, de modo que, a condução procedimental é realizada por sequência de atos que consistem na aplicação do direito processual. Esses atos têm seu conteúdo e, ao isolarmos cada um para análise, pode-se chegar à conclusão de que o específico ato contém um error in judicando. É esse erro em juízo que contamina o ato decisório posteriormente, o que o faz ser retratado como error in procedendo. Isso significa que o error in procedendo supõe um error in judicando. ${ }^{30}$

\subsection{Error in procedendo e anulação de decisão judicial}

O error in procedendo, tradicionalmente, relaciona-se com a anulação da decisão impugnada: o remédio que o ordenamento jurídico normalmente dispõe para consertar a falha procedimental é o desfazimento dos atos viciados e dos que lhes forem dependentes, determinando a retomada do procedimento com nova prática do ato anulado.

No entanto, como se viu, o error in procedendo supõe um error in judicando. Isso quer dizer que seria possível pensar em reforma, em vez de anulação, como resultado do controle de erros procedimentais.

Retomando o exemplo da prova testemunhal indeferida, seria possível imaginar - noutra estruturação do sistema recursal - recurso imediato contra o indeferimento que, ao examinar os pressupostos para a decisão, conclua que era caso de deferir a oitiva da testemunha. Nesse caso, poderse-ia conceber decisão recursal que reformasse a decisão de indeferimento, substituindo-a por uma decisão de deferimento da prova testemunhal.

Como os erros procedimentais supõem erros de julgamento, não é totalmente incompatível imaginar que decisões viciadas que normalmente geram anulação fossem objeto de reforma e substituição. Trata-se de opção estrutural do sistema.

Cabe, no entanto, uma ressalva. O controle de erros procedimentais tem íntima relação com o sistema de nulidades processuais, afinal, anulação supõe reconhecimento de nulidade. É que existem atos decisórios equivocados (erro de juízo) que acabam por tornar nulo o procedimento, como no exemplo do indeferimento de prova injusto, assim como existem atos que são praticados nulamente. Estes últimos não comportam reforma por decisão em sede de recurso.

30 CALAMANDREI, Piero. Sulla distinzione tra error in judicando ed error in procedendo, cit., p. 297. 
Veja-se, por exemplo, a audiência realizada sem a participação indispensável do Ministério Público, a decisão sem fundamentação ou prolatada por juízo incompetente. Nesses casos, não há como simplesmente reformar o ato, é necessário que ele seja praticado novamente. Portanto, nas nulidades intrínsecas à prática do ato, a anulação é fundamental para que ele seja praticado novamente, de modo hígido.

O recurso interposto contra decisão proferida em procedimento nulo ou nulamente conduzido ensejará o seu desfazimento e a renovação do ato nulo, remetendo-se o processo para o juízo a quo para que reconduza o procedimento.

Essa perspectiva relaciona-se com a ideia de que o procedimento hígido deve ser completado todo em primeiro grau. A parte tem direito a passar por postulação válida, por produção de provas válida e a receber decisão válida. Apenas seria possível entender como realmente conclusa a tramitação do processo em primeiro grau a partir do momento em que todo o processo tivesse validamente sido processado e julgado. Depois disso, e apenas depois disso, seria possível a atuação do segundo grau sobre o mérito.

Essa óptica parte de uma potente concepção de duplo grau de jurisdição e gera uma associação entre error in procedendo e anulação de decisões judiciais.

Como se verá adiante, a força dessa percepção vem diminuindo a partir de dois mecanismos processuais: o julgamento direto do mérito e a possibilidade de correção de vícios no próprio tribunal.

\section{Controle da Decisão de Extinção do Processo sem Resolução do Mérito}

Como se viu, nem toda questão processual ensejará um erro de procedimento. Em não poucas situações, a decisão sobre questão processual é conteúdo do ato decisório. Nesse caso, se a questão processual for solucionada equivocadamente, ocorre erro de decisão, error in judicando e não in procedendo.

Realmente, o erro de decisão é aquele que tinge o conteúdo do ato. Ao se resolver questão processual desprovida de vinculação com a condução procedimental, tem-se erro de conteúdo da decisão, a merecer reforma. Não é que o processo devesse ser conduzido doutra forma ou o caminho procedimental eleito revelou-se falho; é a própria decisão que deveria ter outro conteúdo.

Esse fenômeno, já retratado, é intenso nas decisões de admissibilidade do processo.

Veja-se, por exemplo, o caso em que o órgão judicante extingue o processo sem resolução de mérito por entender faltar legitimidade passiva à parte. Legitimidade é questão processual, tratando-se de condição da ação (art. 485, VI, CPC). No entanto, a solução dá-se no conteúdo do ato decisório. Ao se concluir, por exemplo, pela ilegitimidade do filho para propor ação em defesa da honra do pai falecido, tem-se a solução de uma questão processual, que, impugnada, vai ser controlada em seu conteúdo, pretendendo-se a reforma do decisum para que se altere a conclusão a que se chegou. O mesmo quando se extingue o processo porque se considera que determinado órgão público não tem capacidade de ser parte. A decisão, nos dois exemplos, tem conteúdo exclusivamente processual, porém se impugna a aplicação do direito processual, não a condução procedimental. Ela não deve ser anulada, o que revelaria pouca utilidade; é caso de reforma: deve-se não desfazer a decisão, mas substituí-la por outra que reconheça a legitimidade da parte e a capacidade de ser parte.

Tantas outras questões processuais, quando resolvidas, levam a raciocínio idêntico. A distribuição das despesas do processo, por exemplo, é tradicional conteúdo a ser resolvido, que, decidido equivocadamente, não leva a falhas procedimentais, mas a erro de julgamento.

Quando o órgão julgador entende que o procedimento eleito foi errado, e extingue o processo por falta de pressuposto processual, mas o faz equivocadamente, incide em error in judicando. Aplicou-se equivocadamente norma processual onde não incidia. Era o caso de admitir o procedimento e prosseguir até o julgamento do mérito, e não de extingui-lo. O erro está no conteúdo da decisão que extingue o 
processo; não é erro de procedimento. Impugnada a decisão e reconhecida como ilícita, o tribunal não se limitará a cassá-la, mas a reformará, afirmando que houve apropriada eleição de procedimento.

Pois bem.

Nos casos de extinção do processo sem resolução de mérito, há tradicional postura, também fundada numa concepção forte de duplo grau, que entende que o processo deve retornar ao juízo a quo. Isto é, verificado que a decisão impugnada se equivocou ao extinguir o processo sem resolver o mérito, a decisão deveria ser desfeita para que outra decisão seja proferida, desta feita com aptidão para examinar o mérito.

Isto é, a anulação seria o resultado natural do recurso que serve para impugnar a resolução equivocada de questão processual, extinguindo o processo sem resolução de mérito. Havendo a interposição de recurso contra decisão que deixou de julgar o mérito, o tribunal deveria abster-se de resolver o mérito, remetendo o processo para que o juízo prolator da decisão impugnada fizesse o primeiro exame do objeto do processo.

Essa realidade alterou-se já há algum tempo, de modo que parte significativa das decisões de extinção sem resolução de mérito pode ser reformada diretamente por uma decisão de mérito. Na verdade, em tese, toda decisão deste tipo poderia ser substituída por decisão de mérito. Como se passa a ver, o responsável por essa evolução é o julgamento imediato do mérito, que é uma tendência no direito processual brasileiro.

\section{Julgamento Imediato do Mérito em Sede Recursal}

\subsection{Problema de duplo grau de jurisdição}

A partir de 2001, com a Lei 10.352, o Código de Processo Civil (então vigente a Lei 5.869/1973) passou a permitir, em sede de apelação, o ingresso do tribunal diretamente no mérito nos casos em que a apelação impugnasse decisão que extinguiu o processo sem resolução do mérito. ${ }^{31}$ Antes da reforma, não se concebia que, diante de uma "sentença meramente terminativa", o tribunal, ao conhecer do recurso, decidisse sobre a res in iudicium deducta. Para que se ativesse aos limites objetivos do recurso, deveria "resolver apenas a seguinte questão: devia o processo realmente encerrar-se sem tal julgamento?" Caso a resposta fosse negativa, resultando no provimento do recurso, o processo retomaria sua marcha perante o juízo a quo. ${ }^{32}$

Com a reforma, embora a decisão impugnada não tivesse resolvido o mérito, a apelação passou a ser veículo adequado para o tribunal resolver o objeto do processo, desde que reconheça o equívoco na decisão terminativa proferida pelo juízo a quo. O $\$ 3^{\circ}$ do art. 515 do CPC/1973 previa: "Nos casos de extinção do processo sem julgamento do mérito (art. 267), o tribunal pode julgar desde logo a lide, se a causa versar questão exclusivamente de direito e estiver em condições de imediato julgamento”. Assim, o tribunal, em caso de provimento do recurso contra sentença terminativa, substituiria o provimento de extinção sem resolução de mérito por outro que resolve o mérito. ${ }^{33}$

31 Afirmou-se, então, que a modificação fez parte de um conjunto de alterações para "tornar a prestação jurisdicional mais simples, mais rápida e mais eficiente”: THEODORO JR., Humberto. Inovações da Lei 10.353/2001, em matéria de recursos cíveis e duplo grau de jurisdição. Aspectos polêmicos e atuais dos recursos e de outros meios de impugnação às decisões judiciais. São Paulo: RT, 2002, v. 6, p. 263.

32 BARbOSA MOREIRA, José Carlos. Comentários ao Código de Processo Civil, V, cit., p. 419.

33 "A decomposição analítica das pretensões do autor (pretensão ao julgamento do mérito, pretensão ao bem da vida) permite perceber que ocorre uma supressão de grau jurisdicional sempre que o tribunal destinatário da apelação interposta contra sentença terminativa (que se limitou a primeira das pretensões, não se pronunciando sobre a segunda), reformar essa sentença e, dando um passo mais adiante, decidir também a segunda, que não fora objeto de julgamento pelo juiz (a pretensão ao bem da vida). Tradicionalmente, em casos assim cumpria ao tribunal, ao reformar a sentença terminativa e, portanto, afirmar o direito do autor ao julgamento de meritis, devolver o processo ao grau inferior, para que sobre este se pronunciasse o juiz" (DINAMARCO, Cândido Rangel. O efeito devolutivo da apelação e de outros recursos. Nova era do processo civil. 2a ed. São Paulo: Malheiros, 2007, p. 164-165). 
A inclusão do dispositivo suscitou polêmica, especialmente por conta da redução de eficácia do princípio do duplo grau de jurisdição. ${ }^{34}$ A norma instituída no art. 515, § 3o, do CPC/1973 estatuiu que seria possível, em sede recursal, a análise de matérias que não tinham sido solucionadas pelo juízo $a$ quo. Aplicada a regra, o mérito do processo poderia ser decidido unicamente em segunda instância. Para parcela da doutrina, o novo dispositivo normativo teria tolhido o duplo grau, ${ }^{35}$ pois permitiria ao tribunal, ao ensejo de julgar um recurso, adentrar em questões que não foram conhecidas pelo juízo de primeiro grau, pelo que não se poderia falar, por consequência, em verdadeiro duplo grau: haveria apenas um grau de jurisdição dedicado à análise do mérito. ${ }^{36}$ Por essas razões, conforme parcela da doutrina - bem minoritária, é verdade - a norma seria de constitucionalidade duvidosa. ${ }^{37}$

No ponto, é perceptível que o legislador resolveu concretizar de modo menos intenso o duplo grau de jurisdição em favorecimento da celeridade processual. ${ }^{38}$ A legislação brasileira sopesou os dois princípios e optou por prestigiar a duração razoável do processo - que, no momento da reforma, ainda não constava expressamente como direito fundamental (art. 5oㅜ LXXVIII, da CF/1988), mas já era compreendida como aspecto do devido processo legal. Afinal, não se revela razoável a anulação do processo, quando o próprio tribunal tem condições de resolver o seu mérito, evitando o retorno dos autos à primeira instância para nova decisão e, em seguida, ocorrer a muito provável nova subida da causa mediante novo recurso. Com a possibilidade de julgamento imediato do mérito, entende-se como satisfeito o duplo grau de jurisdição com a entrega de uma prestação jurisdicional em primeiro grau e outra em segundo grau, sem vincular ao seu conteúdo, isto é, à satisfação do reexame efetivo das questões.

Proferida sentença pelo juízo a quo, independentemente de ter versado ou não sobre as questões de mérito, torna-se desnecessária a anulação com o regresso dos autos para nova decisão, agora sobre o mérito, bastando que o juízo ad quem decida o caso adequadamente. Enfim, a partir do julgamento imediato do mérito, pode-se afirmar que o direito brasileiro se satisfaz com a existência de duas prestações jurisdicionais, emancipando-se o sistema de qualquer exigência relacionada ao conteúdo delas e sem garantia de efetivo reexame de questões. ${ }^{39}$

34 Para uma visão conservadora do duplo grau: PONTES DE MIRANDA, Francisco Cavalcanti. Comentários ao Código de Processo Civil, VII, cit., p. 38-39.

35 O princípio do duplo grau pode ser compreendido como "possibilidade de reapreciação do mérito da causa, por meio de reexame da decisão final de instância original, abrangendo tanto as questões de fato como as de direito, por órgão jurisdicional diverso, sendo este de hierarquia superior ou não" (MARCATO, Ana Cândida Menezes. Considerações sobre o princípio processual do duplo grau. Teoria do processo - panorama doutrinário mundial. Fredie Didier Jr. (org.). Salvador: Juspodivm, 2010, v. 2, p. 58). Sobre o tema, conferir, amplamente: LASPRO, Oreste Nestor de Souza. Duplo grau de jurisdição no direito processual civil. São Paulo: RT, 1995.

36 A concepção doutrinária tradicional é bem representada na seguinte passagem: "Será sempre o caso de supressão com relação à pretensão de direito material deduzida na petição inicial da ação. Quer dizer, haverá, quanto ao mérito, supressão de um grau de jurisdição, toda vez que estejam presentes os pressupostos de incidência da regra prevista no $\$ 3^{\circ}$ do art. 515” (BANDEIRA DE MELO, Ricardo Procópio. Princípio do duplo grau de jurisdição: garantia constitucional, extensão e alguma notas sobre o $\$ 3^{\circ}$ do art. 515 do CPC. Aspectos polêmicos e atuais dos recursos cíveis e de outros meios de impugnação às decisões judiciais. São Paulo: RT, 2005, v. 8, p. 682). Defendendo tratar-se de exceção ao princípio: APRIGLIANO, Ricardo de Carvalho. A apelação e seus efeitos. 2a ed. São Paulo: Atlas, 2007, p. 156.

37 Assim: PINTO, Nelson Luiz. Manual dos recursos cíveis. São Paulo: Malheiros, 2002, p. 80. Sobre a polêmica: MEDINA, José Miguel Garcia. A recentíssima reforma do sistema recursal brasileiro - análise das principais modificações introduzidas pela Lei 10.352/2001, e outras questões. Aspectos polêmicos e atuais dos recursos e de outros meios de impugnação às decisões judiciais. São Paulo: RT, 2002, v. 6, p. 342-343. Entende ter condição de norma constitucional, decorrente do due process of law, o duplo grau: SÁ, Djanira Maria Radamés de. A atividade recursal civil na reforma do poder judiciário. São Paulo: Pillares, 2006, p. 24. Igualmente: COVAS, Silvano. O duplo grau de jurisdição. De modo semelhante: Aspectos polêmicos e atuais dos recursos. Eduardo Pellegrini de Arruda Alvim; Nelson Nery Jr.; Teresa Arruda Alvim (coord.). São Paulo: RT, 2000, p. 598600. MEDINA, José Miguel Garcia. Direito processual civil moderno, cit., p. 1259-1260. A natureza constitucional do princípio, no entanto, é refutada pela doutrina majoritária e já foi objeto de consideração pelo Supremo Tribunal Federal, que não o considerou de matiz constitucional, entendeu que não se trata de uma garantia das partes e reputou válida a criação de exceções à sua aplicação pela lei ordinária: STF - Plenário, RHC 79.785-RJ, Rel. Min. SEPÚLVEDA PERTENCE, julgado em 29/03/2000, DJ 22/11/2002, p. 57.

38 ASSIS, Araken de. Manual dos recursos. $9^{\mathrm{a}}$ ed. São Paulo: RT, 2017, p. 534.

39 Note-se que esta é a expressão normalmente atribuída ao duplo grau de jurisdição, que, nos sistemas jurídicos em geral, não condiciona a satisfação de seu comando ao efetivo reexame das questões. Nesse sentido, Antonio Carlos Araújo 
Quanto ao duplo grau, enfim, deve-se reconhecer que é menos do que uma garantia, mas, é, sim, uma orientação empírica da disciplina legislativa, sugerido por uma antiga e constante experiência. ${ }^{40}$ O ordenamento jurídico estabelece que, quanto ao mérito (ou qualquer questão), há potencialmente, mas não necessariamente, dois graus de jurisdição - com que, deve-se compreender, dois exames em graus distintos da mesma questão. ${ }^{41}$

Trata-se, enfim, de uma redução de eficácia do princípio do duplo grau totalmente viável por mudança legislativa. ${ }^{42}$

É curioso notar que o dispositivo, na verdade, significou um retorno ao sistema processual brasileiro anterior. Como noticia Machado Gumarães, o direito brasileiro anterior ao CPC/1939 trabalhava com a possibilidade de incursão do tribunal no mérito do processo independentemente de o juízo de primeiro grau tê-lo analisado ou não: "satisfeita a exigência do duplo grau de jurisdição mediante a simples possibilidade de dois exames sucessivos da mesma relação de direito em litígio", logo, não se considerava condição necessária que o respectivo juiz se pronunciasse sobre o mérito da questão; bastaria que tivesse podido fazê-lo. Enfim, nas Ordenações e nas leis processuais anteriores ao CPC/1939, "mesmo que o juiz do primeiro grau não tenha decidido todas as questões de mérito suscitadas pelas partes", estaria "o tribunal da apelação investido do conhecimento integral das aludidas questões, em virtude do efeito devolutivo do recurso". ${ }^{43}$

Todavia, o CPC/1939 passou a exigir que as questões de mérito fossem analisadas pelo juízo de primeira instância para a satisfação do duplo grau - ou, ao menos, foi assim que ele foi lido. ${ }^{44}$ A mesma exigência foi mantida pelo CPC/1973, o que veio a se relativizar apenas com a reforma empreendida pela Lei 10.352/2001.

Assim, o julgamento direto do mérito pelo tribunal, inicialmente nomeado de julgamento da causa madura em sede recursal, teve a sobrelevada importância de ressignificar o duplo grau de

Cintra, em texto de 1986, destacava que no direito austríaco o julgamento direto do mérito pelo tribunal já era a solução adotada, bem como no direito francês, no direito italiano, enquanto no direito alemão se encampava o julgamento direto do mérito como uma faculdade do tribunal, cf. CINTRA, Antonio Carlos de Araújo. Sobre os limites objetivos da apelação civil, cit., p. 78-80. A título exemplificativo, confira-se: GIUDICEANDREA, Nicola. Le impugnazioni civili. Milano: Giuffrè, 1952, v. 2, p. 99-101. O autor menciona que a regra é a pronúncia do juízo de segundo grau sobre o mérito, explicando que previa a lei processual vigente à sua época as hipóteses em que a remessa de volta ao primeiro grau era devida.

40 REDENTI, Enrico; VELLANI, Mario. Diritto processuale civile. Milano: Giuffrè, 2011, p. 436. De modo semelhante, embora conclua que se trata de postulado: VIOLIN, Jordão. Onde está a segurança jurídica? Colegialidade, polarização de grupo e integridade dos tribunais. Revista de Processo. São Paulo: RT, v. 268, 2017, p. 413-414. Sobre o ponto, vale lembrar a famosa crítica: "Da un lato, l'appello come giudizio de novo porta a quella perniciosa svalutazione del giudizio di primo grado, che già s'è menzionata. Dall'altro lato, nessun ordinamento, né in Italia né in qualsiasi altro paese - tanto meno in Francia, dove l'idea del 'double degré de jusdiction' pur sembra essere particolarmente radicata - considera il doppio grado di giurisdizione come una garanzia costituzionale, protetta cioè come una garanzia fondamentale e inderogabile. Al contrario, le deroghe ci sono, sono frequenti e, neanche a farlo apposta, si riferiscono assai spesso alle cause di minor valore ossia, nella maggior par dei casi, alle cause dei poveri" (CAPPELLETTI, Mauro. Parere iconoclastico sulla riforma del processo civile. Giustizia e società. Milano: Edizione di Comunità, 1972, p. 117).

41 MONTELEONE, Girolamo. Diritto processuale civile. $8^{\mathrm{a}}$ ed. Milano: CEDAM, 2018, v. II, p. 602. Ver, também, com muito proveito, a conclusão de que não vige o tantum appellatum quantum iudicatum, mas que o duplo grau significa, apenas, a dupla possibilidade de exame de mérito: ZANZUCCHI, Marco Tullio. Nuove domande, nuove eccezioni e nuove prove in appello. Milano: Società Editrice Libraria, 1916, p. 138-142.

42 Assim: SANTOS, Ernane Fidélis dos. Evolução legislativa do sistema recursal de primeiro grau no Código de Processo Civil brasileiro. Meios de impugnação ao julgado civil - Estudos em homenagem a José Carlos Barbosa Moreira. Adroaldo Furtado Fabrício (coord.). Rio de Janeiro: Forense, 2007, p. 211.

43 MACHADO GUIMARÃES, Luiz. Efeito devolutivo da apelação. Estudos de direito processual civil. Rio de Janeiro-São Paulo: Jurídica e Universitária, 1969, p. 217-218. Também destaca esse ponto, bem como a existência de regras similares em sistemas estrangeiros: MALLET, Estêvão. Reforma de sentença terminativa e julgamento imediato do mérito (Lei 10.352). Aspectos polêmicos e atuais dos recursos cíveis e de outros meios de impugnação às decisões judiciais. Nelson Nery Jr. e Teresa Arruda Alvim (coord.). São Paulo: RT, 2003, v. 7, p. 184-186.

44 "O nôvo Código de Processo Civil, porém, quebrando essa tradição, foi mais rigoroso e preciso na conceituação do duplo grau de jurisdição, exigindo, como condição de admissibilidade do segundo exame pleno, uma decisão sôbre o mérito proferida em primeira instância” (MACHADO GUIMARÃES, Luiz. Efeito devolutivo da apelação, cit., p. 218). 
jurisdição na justiça cível brasileira, atribuindo-lhe uma perspectiva mais coerente. ${ }^{45}$ Antes, consideravase que o duplo grau teria sido infringido se o juiz prolatasse uma sentença terminativa e o tribunal proferisse uma decisão de mérito, pois as questões decididas por este não teriam sido examinadas por aquele, condicionando, na hipótese, a preservação do duplo grau à efetiva ocorrência de duplo exame das mesmas questões. ${ }^{46}$

Essa perspectiva parece mais adequada, pois, por exemplo, em caso de cumulação de defesas, tendo o magistrado adotado a primeira delas - pelo que deixa de analisar as posteriores -, não se considerava existir supressão de instância se o tribunal, entendendo inadequada a tese acolhida na sentença, passasse a analisar as demais teses defensivas (norma hoje encampada no art. 1.013, $§ 2^{\circ}$, do CPC). ${ }^{47}$ Diga-se o mesmo quando o tribunal reformasse sentença de mérito para proferir decisão terminativa com base em questão não conhecida pelo juiz. Com a Lei 10.352/2001 inicia-se a generalização da seguinte base conceitual: o que importa é a prestação jurisdicional, sendo irrelevante o teor de seu conteúdo; uma vez tendo sido proferida uma decisão, cabe ao tribunal distribuir justiça do modo adequado, resolvendo as questões pertinentes, mesmo que não tenham sido abordadas na decisão impugnada - e desde que a causa esteja "madura" para julgamento. ${ }^{48}$

De fato, a mudança revelou-se tão importante que se chegou a afirmar que o sistema recursal brasileiro, a partir da possibilidade do julgamento direto do mérito pelo tribunal, deixou de ter natureza de revisio prioris instantiae e passou a ser caracterizado, na hipótese, como verdadeiro novum iudicium, permitindo-se ao órgão jurisdicional superior o mais amplo exame da causa, nas questões de fato e de direito, julgando-a ex novo. ${ }^{49}$

\subsection{Aplicação do julgamento imediato do mérito}

Na doutrina, após a inclusão da norma no sistema, eram recorrentes discussões acerca de dois pontos, o primeiro: o emprego do verbo "pode", o que significaria uma faculdade do tribunal decidir o mérito diretamente, segundo seu critério discricionário; ou, por outra perspectiva, significaria a necessidade de que a parte, em seu recurso, deduzisse pedido expresso no sentido do julgamento direto do mérito; ou, ainda, seria apenas um mau uso terminológico, que não reduziria a cogência da norma, pelo que seria um imperativo da duração razoável que o tribunal, percebendo a hipótese de aplicação da norma, ingressasse no julgamento direto do mérito. ${ }^{50} \mathrm{~A}$ segunda questão era ligada à expressão

45 "No direito europeu nunca houve necessidade de dispositivo semelhante, porque sempre se aceitou a causa madura como uma consequência do princípio do duplo grau de jurisdição. Contudo, no direito brasileiro, o princípio era interpretado de forma sui generis, prevalecendo o entendimento de que o direito ao duplo grau de jurisdição garantia às partes dois julgamentos de mérito. A partir dessa orientação, a doutrina e a jurisprudência pátrias entendiam que se o juiz tinha extinguido o processo sem julgamento do mérito e o autor apelasse pedindo a reforma da sentença, o tribunal, reconhecendo o erro da decisão recorrida, tinha de anulá-la e devolver ao juiz de primeiro grau o julgamento da causa, para que ele próprio proferisse uma nova sentença” (GRECO, Leonardo. Instituições de processo civil. Rio de Janeiro: Forense, 2015, v. III, p. 104).

46 "Quanto às sentenças terminativas sem julgamento do mérito, há dissolução do que se julgou; de modo que somente isso vai ao conhecimento do órgão ad quem. Se esse conhecesse o que não foi objeto de apelação estaria a infringir as regras jurídicas de competência, o princípio do duplo grau de jurisdição, que está à base da apelação" (PONTES DE MIRANDA, Francisco Cavalcanti. Comentários ao Código de Processo Civil, VII, cit., p. 172).

47 BOLZANI, Virginia Brodbeck. Efeito devolutivo da apelação. Rio de Janeiro: Aide, 2001, p. 102.

48 Nesse sentido: LASPRO, Oreste Nestor de Souza. Duplo grau de jurisdição no direito processual civil. São Paulo: RT, 1995, p. 164-166. Igualmente destacando hipóteses em que situações similares ocorriam e que "já havia em nosso ordenamento outras hipóteses de supressão de grau de jurisdição": OLIVEIRA, Pedro Miranda de. O duplo grau de jurisdição e o julgamento imediato pelos tribunais no CPC/2015. Aspectos polêmicos dos recursos cíveis e assuntos afins, v. 13. São Paulo: RT, 2017, p. 413-414.

49 TUCCI, José Rogério Cruz e. Lineamentos da nova reforma do CPC. 2ª ed. São Paulo: RT, 2002, p. 99.

50 Sobre o debate, conferir: APRIGLIANO, Ricardo de Carvalho. A apelação e seus efeitos, cit., p. 163-170. Ver também: MALLET, Estêvão. Reforma de sentença terminativa e julgamento imediato do mérito (Lei 10.352), cit., p. 194-197. 
"questão unicamente de direito", bem como à exigência de "condições de imediato julgamento", ${ }^{51}$ que a doutrina se dedicava a esclarecer, chegando à conclusão, majoritária, de que significava a desnecessidade de produção de provas. ${ }^{52}$

No CPC/2015, a regra ganhou ainda mais abrangência e não olvidou os pontos objeto de atenção doutrinária.

A norma preconiza que o tribunal deve decidir desde logo o mérito quando o processo estiver em condições de imediato julgamento. $\mathrm{O}$ art. $1.013, \S 3^{\circ}$, previu a decisão imediata do mérito como poderdever do tribunal, o que quer dizer que a aplicação da regra independe de pedido da parte e não pode ser afastada pelo desinteresse do tribunal em aplicá-la. ${ }^{53} \mathrm{O}$ julgamento imediato do mérito é um efeito atribuído ao reconhecimento de alguma das hipóteses previstas em seus incisos, logo, o tribunal deve passar ao julgamento do mérito quando, encontrando-se o processo apto a ser julgado, reconhecer que houve a extinção sem resolução de mérito indevida ou decretar a nulidade por falta de congruência ou por falta de fundamentação adequada. ${ }^{54}$ Trata-se da eficácia legal de uma decisão nesse sentido, determinando o prosseguimento do procedimento recursal para a solução do mérito do processo. Não há, para a incidência da norma, a previsão em seu suporte fático de qualquer tipo de manifestação de vontade ou de assentimento das partes; trata-se de um ato-fato. ${ }^{55} \mathrm{E}$, com efeito, uma regra de julgamento para as hipóteses enumeradas no art. 1.013, que precisa ser observada. ${ }^{56}$ Caso o tribunal deixe de proceder com o julgamento imediato do mérito, comete erro de procedimento. ${ }^{57}$

Quanto à substituição da expressão "questão exclusivamente de direito" por "condições de imediato julgamento", a regra tornou-se mais adequada: não se assegura uma dupla resolução das questões de fato. Não há direito de ter um primeiro julgamento do juízo a quo quanto às questões fático-probatórias para que, em seguida, possa o tribunal revisá-las. ${ }^{58}$ A exigência para a aplicação do instituto é de que o processo esteja apto a ser decidido pelo juízo ad quem, pouco importando se as questões que deve resolver são exclusivamente de fato, exclusivamente de direito, ou que ambos os tipos de questões precisem ser resolvidas. Realmente, a regra pode ser aplicada mesmo que existam questões fáticas a serem solucionadas, bastando que estejam tais questões em condições de imediato julgamento, ou seja, que a prova já tenha sido produzida ou que seja desnecessária. ${ }^{59}$ Caso contrário,

51 Os dois pressupostos, na verdade, sobrepunham-se, cf. BARBOSA MOREIRA, José Carlos. Comentários ao Código de Processo Civil, $V$, cit., p. 431.

52 Com compilação doutrinária a respeito, conferir: GONÇALVES, Mauro Pedroso. Recurso de apelação e novas aplicações de seu efeito devolutivo. Curitiba: Juruá, 2009, p. 87-90.

53 BONDIOLI, Luis Guilherme Aidar. Comentários ao Código de Processo Civil. São Paulo: Saraiva, 2016, v. XX, p. 113.

54 BEDAQUE, José Roberto dos Santos. Apelação: admissibilidade e efeitos. Aspectos polêmicos e atuais dos recursos cíveis e de outros meios de impugnação às decisões judiciais. Nelson Nery Jr. e Teresa Arruda Alvim (coord.). São Paulo: RT, v.7, 2003, p. 448.

55 Sobre o conceito de ato-fato processual: CAMPOS, Eduardo. Ato-fato processual: reconhecimento e consequências. Revista de Processo, v. 254, p. 75-90, 2016.

56 SIQUEIRA, Thiago Ferreira. Duplo grau de jurisdição e "teoria da causa madura" no novo Código de Processo Civil. Coleção novo CPC: Doutrina Selecionada - Processo nos tribunais e meios de impugnação às decisões judiciais. Lucas Buril de Macêdo; Ravi Peixoto; Alexandre Freire (org.). 2a ed. Salvador: Juspodivm, 2016, p. 863. Assim, com razão, afirma-se que a norma tolheu o princípio dispositivo em grau recursal: BARIONI, Rodrigo. Efeito devolutivo da apelação, cit., p. 164-165. Porém, não é correta a associação com o efeito translativo, feita em: QUEIROZ, Pedro Gomes de. A apelação no CPC/2015, cit., p. 189-190.

57 Em sentido contrário, entendendo que o retorno para o primeiro grau deve ser analisado caso a caso pelo tribunal, de acordo com a sua conveniência, inclusive pedagógica (no caso de falta de fundamentação): ASSIS, Araken de. Manual dos recursos, cit., p. 537.

58 GRECO, Leonardo. Instituições de processo civil, cit., v. III, p. 104-105.

59 Nesse sentido: USTÁRROZ, Daniel; PORTO, Sergio Gilberto. Manual dos recursos cíveis. 6⿳a ed. Porto Alegre: Livraria do Advogado, 2017, p. 151-152. Já propunha essa solução mesmo no sistema anterior: MALLET, Estevão. Reforma de sentença terminativa e julgamento imediato do mérito. Aspectos polêmicos e atuais dos recursos cíveis e de outros meios de impugnação às decisões judiciais. São Paulo: RT, 2003, v. 7, p. 193. SILVA, Márcio Henriques Mendes da. Tentativa de sistematização do efeito devolutivo dos recursos. Aspectos polêmicos e atuais dos recursos cíveis. Nelson Nery e Teresa Arruda Alvim (coord.). São Paulo: RT, 2007, v. 11, p. 218-219. 
o campo de incidência da norma seria diminuto: é raro que não se apresente uma questão fática, ainda que solucionável mediante prova exclusivamente documental, o que reduziria sobremaneira a aplicabilidade do julgamento imediato do mérito ${ }^{60}$ Estando o processo pronto para a tomada de decisão quanto ao mérito, sem necessidade de dilação procedimental, aplica-se o julgamento imediato do mérito ${ }^{61}$ Normalmente, a regra é interpretada da seguinte maneira: sendo desnecessário percorrer procedimento para a produção de provas, é possível o imediato julgamento do mérito.

Conforme previsão do CPC/2015, o instituto é aplicável nos casos em que houver decisão com vício de fundamentação, nula por falta de congruência, omissa no exame de pedido, de extinção sem resolução do mérito ou de extinção com resolução do mérito por prescrição ou decadência. Nessas hipóteses, o tribunal deverá ingressar no objeto litigioso do processo, desde que não exista alguma razão impeditiva que recomende o retorno do processo ao primeiro grau, nomeadamente a necessidade de trilhar o procedimento de produção de provas ou de seguir caminhos procedimentais outros para a prolação de decisão válida.

Note-se que as novas hipóteses previstas no $\$ 3^{0}$ do art. 1.013 trazem errores in procedendo, que tradicionalmente ensejavam a anulação da decisão, de modo que, antes da previsão do julgamento imediato do mérito, ficava determinado ao juízo a quo que retomasse o processo e prolatasse nova decisão, desta vez com a atenção e o cuidado para não incidir no mesmo vício. ${ }^{62}$ Com a configuração atual do julgamento imediato do mérito pelo tribunal, ocorre a imediata substituição da decisão eivada de nulidade por uma decisão, que, reconhecendo tal vício, passa a corrigi-lo. ${ }^{63}$

No inciso II prevê-se a decisão imediata do mérito quando o tribunal "decretar a nulidade da sentença por não ser ela congruente com os limites do pedido ou da causa de pedir". Nos casos em que a sentença for extra petita ou extra causa petendi, portanto, decidindo sobre coisa diversa daquela demandada, seja pelos limites estipulados no pedido ou na causa de pedir, o juízo ad quem reconhecerá o vício, decretará a nulidade e, em seguida, proferirá nova decisão, desta vez atendo-se aos limites objetivos da demanda.

Coisa diversa ocorre se a decisão for ultra petita. Neste caso é plenamente suficiente a decretação de nulidade da parcela do dispositivo da decisão que ultrapassou a fronteira do pedido. Não há sentido, nesta hipótese, em proferir nova decisão, uma vez que basta a eliminação do que transbordou ao pedido para regularizar a sentença, extirpando o error in procedendo ${ }^{64}$

Deve se destacar que as hipóteses previstas nos incisos do art. 1.013, § 3oo, não exaurem a aplicabilidade do dispositivo. O tribunal deve proceder ao julgamento imediato do mérito sempre que preenchido o seu requisito fundamental: estiver a causa em condições para ser julgada. Ocorrendo isso, não se justifica a anulação da sentença ou, mais propriamente, a remessa ao primeiro grau.

Veja-se, por exemplo, o que ocorre nos casos de cumulação de causas de pedir, cumulação de defesas, ou de dedução de pedidos subsidiários: em todas essas hipóteses o juiz de primeiro grau pode deixar de analisar questões que o tribunal deve resolver, se reconhecer razão na impugnação. Na verdade, a decisão imediata do mérito é uma opção de estruturar o sistema de modo a privilegiar a duração razoável do processo em vez do amplo reexame de questões, que se revela como uma alternativa

60 SIQUEIRA, Thiago Ferreira. Duplo grau de jurisdição e "teoria da causa madura" no novo Código de Processo Civil, cit., p. 861.

61 Discorda-se da conclusão de que o dispositivo só se aplica em casos passíveis de julgamento antecipado do mérito: BARIONI, Rodrigo. Efeito devolutivo da apelação, cit., p. 167.

62 ARRUDA ALVIM, Eduardo; ARRUDA ALVIM, Angélica; FERREIRA, Eduardo Aranha. Os efeitos devolutivo e translativo da apelação no CPC/2015. In: Nelson Nery Jr.; Teresa Arruda Alvim (coord.). Aspectos polêmicos dos recursos cíveis e assuntos afins, v. 13. São Paulo: RT, 2017, p. 150.

63 "Não se trata, destarte, de relevar a nulidade da sentença, mas, na verdade, de verificar a possibilidade de que, após a sua pronúncia, o órgão ad quem julgue desde logo o mérito" (SIQUEIRA, Thiago Ferreira. Duplo grau de jurisdição e "teoria da causa madura” no novo Código de Processo Civil, cit., p. 870).

64 Já defendia a solução dessa forma, inclusive citando precedentes judiciais nesse sentido: CINTRA, Antonio Carlos de Araújo. Sobre os limites objetivos da apelação civil. São Paulo, 1986, p. 80-81. No CPC atual: DIDIER JR, Fredie; CUNHA, Leonardo Carneiro da. Curso de direito processual civil. 13ㅜㅡㄹ ed. Salvador: Juspodivm, 2016, v. 3, p. 198. 
custosa e ineficiente, e, por isso mesmo, foi descartada. A ratio essendi do instituto é evitar idas e vindas do processo, com os custos e prejuízos a isso inerentes, cumprindo ao tribunal resolver diretamente o objeto do processo sempre que possível. Essa diretriz se manifesta nas hipóteses previstas expressamente na regra do $\S 3^{\circ}$ do art. 1.013, mas deve ser seguida quando presentes as mesmas razões; logo, deve-se proceder com a resolução direta do objeto do processo toda vez que ela for viável. ${ }^{65}$

Há quem defenda que, sendo hipótese de aplicação do art. 1.013, § 3o, do CPC, estar-se-ia diante de caso de "competência originária para o julgamento da causa" do tribunal. ${ }^{66}$ Mesmo que o tribunal analise o mérito pela primeira vez, não é correto falar em competência originária. A competência originária é para a propositura de ação, o que não é o caso: o tribunal analisa o mérito no procedimento recursal, e foi o recurso que legitimou a atuação jurisdicional. Não se pode confundir as coisas: o que autoriza o processamento e a decisão pelo tribunal, seja na revisão de questões decididas ou na resolução de questões que não foram analisadas em primeiro grau, é um recurso e não uma ação; dizer que se trata de primeira análise da matéria não significa que isso será feito, necessariamente, em exercício de competência originária. A competência do tribunal é para decidir o recurso, o que foi alterado foi o objeto do juízo recursal, e não a natureza da competência. ${ }^{67}$

Na aplicação do julgamento imediato do mérito é necessária uma cautela importante, que o regramento legal não deixa clara. É fundamental que o tribunal se preocupe em implementar o contraditório.

Muito embora tal alerta pareça desnecessário, sobretudo em virtude do reforço do direito de participação e do contraditório e da consagração da proibição de decisão-surpresa, que se encontram nos arts. 9o e 10 do CPC, ele é essencial, já que o próprio Código deixou de destacar o contraditório no julgamento direto do mérito, levando a crer que, assim como se procedia no sistema processual predecessor, é lícito ao órgão jurisdicional prosseguir para o julgamento do mérito sem intimar os interessados para que se manifestem. No procedimento recursal, as partes não tiveram a oportunidade de se direcionarem ao órgão jurisdicional para convencê-lo das razões pelas quais merecem um julgamento de mérito favorável. O recurso impugna a decisão, que não versa sobre o mérito do processo; logo, não pode o recurso ou as contrarrazões serem tidas como uma oportunidade adequada para manifestação sobre o mérito do processo. ${ }^{6}$

Desse modo, a correta condução do procedimento recursal exige que o órgão judicante, ao deliberar ser caso de aplicação do $\$ 3^{\circ}$ do art. 1.013, convencendo-se de que é devido o ingresso no mérito do processo, converta o julgamento em diligência, intimando as partes para que se manifestem sobre a matéria (art. 933 do CPC). Depois disso, deve incluir o processo novamente em pauta, garantindo às partes o direito à sustentação oral. Sem isso, tolhe-se injustificadamente o direito de participação e o contraditório. ${ }^{69}$

Finalmente, é de se enfatizar que dispositivo normativo deve ser lido, antes de tudo, como uma diretriz para a tomada de decisão em juízos recursais - é, sob esse aspecto, também uma manifestação da primazia do mérito. Isso significa que é permitido - e mais do que isso, desejável -, que, em hipóteses não listadas similares o mérito seja diretamente resolvido em sede recursal: afinal, a norma nada mais é do que "um atalho, legitimado pela aptidão a acelerar os resultados do processo e desejável sempre

65 Assim também: GRECO, Leonardo. Instituições de processo civil, cit., v. III, p. 105-106.

66 JORGE, Flávio Cheim. Teoria geral dos recursos cíveis. 7ª ed. São Paulo: RT, 2015, p. 365.

67 BARIONI, Rodrigo. A proibição da reformatio in peius e o $\$ 3^{\circ}$ do art. 515 do CPC. Aspectos polêmicos e atuais dos recursos cíveis e de outros meios de impugnação às decisões judiciais. São Paulo: RT, 2005, v. 8, p. 715-716. O processualista paulista constrói o raciocínio da competência recursal funcional como justificativa para a prescindibilidade do pedido do recorrente para que o tribunal decidisse o mérito diretamente, levando em consideração a sistemática do CPC/1973. Similarmente: GONÇALVES, Mauro Pedroso. Recurso de apelação e novas aplicações de seu efeito devolutivo. Curitiba: Juruá, 2009 , p. 100-105.

68 Este alerta já havia sido feito mesmo antes do CPC/2015, tomando em conta a reforma do Código de 1973: TUCCI, José Rogério Cruz e. Lineamentos da nova reforma do CPC. 2ª ed. São Paulo: RT, 2002, p. 101. 
que isso for feito sem prejuízo a qualquer das partes".70 Pense-se, por exemplo, na extinção parcial do processo, quanto a uma pretensão deduzida em juízo. Em sede de agravo de instrumento é possível que, preenchidos os requisitos do art. 1.013, § 3º, proceda-se diretamente à resolução do mérito do processo. Deve-se, enfim, sempre que possível, preferenciar a resolução imediata do mérito, como mecanismo de efetivação da eficiência processual e da duração razoável do processo. ${ }^{71}$

O julgamento direto do mérito promove a ampliação do objeto do juízo recursal. O recurso versa sobre um error in iudicando (inc. I), em que se aplicou equivocadamente uma norma que leva à inadmissibilidade do processo, ou um error in procedendo, por falha no dever de congruência (inc. II e III) ou na fundamentação da decisão (inc. IV). São esses erros de decisão que podem ser efetivamente impugnados. Não há impugnação, no recurso, quanto ao mérito, pela simples razão de que o mérito não foi resolvido. Todavia, permite-se a ampliação do objeto do juízo recursal, desprendendo-lhe do recurso e da decisão impugnada, de modo a autorizar que verse sobre questão principal diversa, resgatando o objeto do processo e permitindo, assim, a solução direta do mérito. ${ }^{72}$

Por essa perspectiva, fica evidente que a decisão imediata do mérito pelo tribunal não é decorrente do recurso, propriamente dito, mas, sim, de um efeito atribuído à procedência da impugnação, que atua independentemente da vontade do recorrente. É uma decorrência legal do fato da decisão de procedência do recurso, que tem por eficácia a instauração do procedimento, em sede recursal e talvez sem solução de continuidade, para decisão do mérito do processo. ${ }^{73}$

Isso torna claro que a decisão do mérito não enseja reformatio in peius. ${ }^{74}$ Não é que o tribunal reforme a sentença para colocar em seu lugar uma decisão de mérito, que pode ser desfavorável. Na verdade, a decisão do pedido recursal volta-se a declarar que não era o caso de extinção sem resolução do mérito ou a decretar a nulidade da sentença. A decisão de mérito que se segue não é decorrência do recurso, mas da ampliação do objeto do juízo recursal, estabelecida no art. 1.013, § 3o do CPC: resgatamse os pedidos das partes, na ação e na defesa, para que se resolva o objeto do processo.

Isso, inclusive, impacta na deliberação do órgão colegiado: delibera-se quanto ao recurso, propriamente dito, no sentido do reconhecimento do error in procedendo ou in judicando; depois, caso procedente o pedido recursal, sucessivamente se passa à deliberação do mérito do processo. São duas deliberações que não se confundem e que precisam ser identificadas no acórdão apartadamente.

A decisão do mérito no procedimento recursal não reforma a decisão de primeiro grau - até porque não houve sequer decisão de mérito a ser reformada -, ela acrescenta algo novo. Não há, desse modo, que se falar em reforma para pior, na medida em que a decisão do tribunal não está efetivamente a reformar nada, mas a decidir pela primeira vez sobre o mérito. ${ }^{75}$

70 DINAMARCO, Cândido Rangel. O efeito devolutivo da apelação e de outros recursos, cit., p. 180.

71 Já defendia a interpretação extensiva do julgamento direto do mérito no CPC/1973: GONÇALVES, Mauro Pedroso. Recurso de apelação e novas aplicações de seu efeito devolutivo, cit., p. 118-154.

72 Semelhantemente: BARIONI, Rodrigo. A proibição da reformatio in peius e o $\$ 3^{0}$ do art. 515 do CPC. Aspectos polêmicos e atuais dos recursos cíveis e de outros meios de impugnação às decisões judiciais. São Paulo: RT, 2005 , v. 8, p. 703.

73 Equivocadamente relaciona o julgamento direto do mérito com a profundidade do efeito devolutivo e com o efeito translativo: GRANADO, Daniel Willian. Recurso de apelação no novo Código de Processo Civil, cit., p. 157 e 171.

74 Contrariamente: BEDAQUE, José Roberto dos Santos. Apelação: admissibilidade e efeitos, cit., p. 454. LOPES, Bruno Vasconcelos Carrilho. A reformatio in peius no direito processual civil. In: Nelson Nery Jr. e Teresa Arruda Alvim (Coord.). Aspectos polêmicos e atuais dos recursos cíveis e de outros meios de impugnação às decisões judiciais. São Paulo: RT, 2005, v. 8, p. 37. BONDIOLI, Luis Guilherme Aidar. Comentários ao Código de Processo Civil, XX, cit., p. 111-112. KOZIKOSKI, Sandro Marcelo. O CPC 2015 e a relativização do princípio da proibição da reformatio in pejus. Coleção novo CPC: Doutrina Selecionada - Processo nos tribunais e meios de impugnação às decisões judiciais. Lucas Buril de Macêdo; Ravi Peixoto; Alexandre Freire (org.). 2a ed. Salvador: Juspodivm, 2016, p. 648-649.

75 Nesse sentido: BARIONI, Rodrigo. A proibição da reformatio in peius e o $\$ 3^{-}$do art. 515 do CPC, cit., p. $717-718$. Assim também, já levando em consideração o Código vigente: OLIVEIRA, Pedro Miranda de. O duplo grau de jurisdição e o julgamento imediato pelos tribunais no CPC/2015. Aspectos polêmicos dos recursos cíveis e assuntos afins, v. 13. São Paulo: RT, 2017, p. 416-418. ASSIS, Araken de. Manual dos recursos. 9ª ed. São Paulo: RT, 2017, p. 144-145. 
Poder-se-ia pensar que, pragmaticamente, é possível verificar uma reforma para pior, e que, como ela é medida pela consequência prática, haveria, aí, uma reformatio in peius permitida pelo ordenamento brasileiro. ${ }^{76}$ De fato, do ponto de vista prático há a piora da situação.

Porém, não adianta falar de peius do ponto de vista prático, se não há reformatio. A reforma para pior está ligada à alteração para pior de uma determinada situação jurídica, que foi declarada judicialmente e submetida a recurso. ${ }^{77}$ No caso do julgamento direto do mérito, não é a situação jurídica declarada judicialmente e submetida a recurso que é piorada. No provimento impugnado, afirmava-se a inexistência do direito do recorrente a um provimento de mérito, o que é reformado para garantir esse direito. No exame do mérito pelo tribunal é examinada outra situação jurídica, diversa da impugnada.

A decisão do 1.013, § 3o, do CPC não reforma nada, ela é um novo juízo, que tem por objeto matéria diversa da impugnada. Não se pode falar de reforma para pior se não se trata de reforma. Portanto, do ponto de vista analítico, não é adequado falar em reformatio in peius no julgamento direto do mérito em recurso.

\subsection{Considerações sobre o julgamento imediato de mérito no recurso e a anulação de decisões judicíais}

Com a regra entabulada no art. 1.013, § 3ํㅡㄹ do CPC, encampou o Código de Processo Civil verdadeira diretriz no sentido de que o mérito do processo deve ser decidido em grau recursal sempre que isso for possível.

Com isso, deu visão mais coerente ao princípio do duplo grau, que deve ser compreendido como norte determinando que seja viabilizado, sempre que possível, dois graus jurisdicionais para o exame do objeto do processo. Porém, o princípio do duplo grau não fornece nenhuma garantia de reexame, isto é, de que o mérito ou qualquer outra questão será, necessariamente, examinada em dois graus de jurisdição.

Acontece, no entanto, que há limite à aplicabilidade do julgamento imediato do mérito. Esse limite é representado pela locução "se o processo estiver em condições de imediato julgamento", utilizada pelo $\$ 3^{\circ}$ do art. 1.013 do CPC. Isso significa que apenas é possível prosseguir com o imediato julgamento do mérito em recurso quando houver, no processo, contraditório perfeito, em especial, quando não for necessário conduzir dilação probatória.

Todavia, parece que a regra processual ficou aquém do que poderia ter sido. O próprio Código de Processo outorga ao tribunal ferramentas que poderiam viabilizar, de logo, o julgamento imediato do mérito. Essas ferramentas são a possibilidade de correção de vícios processuais e a permissão de produção de provas no tribunal.

Passamos a examiná-las.

\section{Produção de Provas pelo Tribunal no Procedimento Recursal}

O direito processual organiza-se em fases, que geram, por consequência, a preclusão de atos pertinentes aos momentos processuais que se sucederam. Isso ocorre também quanto à produção probatória. Os documentos são produzidos na petição inicial e na contestação (art. 434 do CPC), ou na réplica (art. 350 do CPC). Superada a fase postulatória, o juízo deve sanear o feito e organizá-lo para

76 Destacando que, tradicionalmente, a reforma para pior é examinada do ponto de vista prático: BARBOSA MOREIRA, José Carlos. Comentários ao Código de Processo Civil, cit., p. 432-433. BARBOSA MOREIRA, José Carlos. Reformatio in peius (Processo Civil). Direito processual civil (ensaios e pareceres). Rio de Janeiro: Borsoi, 1971, p. 147. Frise-se, porém, que o conceito leva em conta decisões de meritis, de modo que a sua aplicação sem as devidas adaptações às particularidades do julgamento direto, em que se profere decisão de mérito a partir da impugnação a decisão terminativa, é uma extensão injustificada do conceito.

77 Conferir: TONIOLO, Ernesto José. A evolução do conceito de reformatio in peius e a sua proibição no sistema recursal do processo civil. Revista de Processo. São Paulo: RT, v. 254, 2016, p. 257-280. 
a fase instrutória (art. 357 do CPC), momento no qual se especifica a qual dos sujeitos incumbe o ônus probatório de cada questão fática e as provas admitidas (art. 357, II e III, do CPC). Na instrução a prova é produzida e, então, o processo torna-se pronto para a sentença.

Na fase recursal, portanto, normalmente a produção de prova é desnecessária, pois já foi produzida. Caso alguma das partes repute importante produzir uma prova que deixou de ser feita na fase adequada, o direito à sua produção já precluiu: o recurso não serve como mecanismo para corrigir os erros de atuação dos sujeitos parciais. ${ }^{78}$ Percebe-se que, em princípio, não se produzem provas nos recursos. ${ }^{79}$ Isso, como se vê, porque a estruturação recursal pressupõe que a instrução da causa já foi realizada, tratando-a como um momento processual superado. ${ }^{80}$

A regra - ou, ao menos, o regular - é que não se produzem provas nos recursos, pois todos os elementos comprobatórios devem ser oferecidos na primeira fase da relação processual. ${ }^{81}$

Todavia, a decorrência lógica de se poder alegar novos fatos em sede recursal (arts. 342, I, $493 \mathrm{e}$ 1.014, CPC) é que as partes podem produzir as suas respectivas provas. Afinal, não faria sentido poder alegar fatos sem a correspondente possibilidade de demonstrá-los: a permissão legal de afirmação seria uma inutilidade sem a decorrente permissão para se desincumbir do respectivo ônus da prova. ${ }^{82}$ Do mesmo modo, a lei processual seria incoerente se permitisse ao terceiro a impugnação da decisão judicial (art. 996), proibindo-o, porém, de fazer prova de suas alegações..$^{83}$ Inequivocamente, para os fatos alegáveis pela primeira vez no recurso, vale o direito à prova como componente do direito de acesso à justiça: para esses, não cabe qualquer limitação do regular direito à prova, como concebido para o primeiro grau, aplicando-se o mesmíssimo regime probatório. ${ }^{84}$

Mesmo diante dessa constatação lógica, o processo civil brasileiro, durante significativo espaço temporal, manteve-se agrilhoado ao dogma de que seria impossível a produção de provas em tribunal. Apesar da indigitada contradição, que permitia novas alegações fáticas e vedava a produção de provas, era assente a inviabilidade de instrução processual nos tribunais. ${ }^{85}$

A objeção fundava-se na inviabilidade estrutural de provas serem produzidas em tribunal e no custo temporal que a instrução significaria. O tribunal, por ser um órgão de julgamento de recursos, não teria a estrutura adequada para a produção de provas e para a realização de audiências de instrução. Seria também incômodo para a Corte a condução de procedimentos probatórios, que se tornariam excessivamente custosos, pois seria bastante difícil conciliá-los com a colegialidade. ${ }^{86}$

$78 \quad$ "No sistema processual brasileiro, como, atualmente, no italiano, o segundo grau serve apenas para corrigir erros ou omissões eventuais do primeiro juiz, não servindo, entretanto, ao contrário do que pretendia Redenti, para corrigir erros eventuais da conduta processual das partes. Isto porque o nosso sistema limita consideravelmente o segundo grau, proibindo a produção de novas provas no processo de apelação (art. 223)" (MARTINS, Pedro Batista. Recursos e processos de competência originária dos tribunais. Rio de Janeiro: Forense, 1957, p. 195).

79 CINTRA, Antônio Carlos de Araújo. Apontamentos sobre os fatos da causa e a apelação. Meios de impugnação ao julgado civil - Estudos em homenagem a José Carlos Barbosa Moreira. Adroaldo Furtado Fabrício (coord.). Rio de Janeiro: Forense, 2007, p. 97-99.

80 PONTES DE MIRANDA, Francisco Cavalcanti. Comentários ao Código de Processo Civil, VII, p. 162.

81 FAGUNDES, Miguel Seabra. Dos recursos ordinários em matéria civil. Rio de Janeiro: Forense, 1946 , p. 217.

82 BARbOSA MOREIRA, José Carlos. Comentários ao Código de Processo Civil, V, cit., p. 456.

83 BARIONI, Rodrigo. Efeito devolutivo da apelação, cit., p. 145.

84 TEODOLDI, Alberto. L'appello civile. Torino: Giappichelli, 2016, p. 335.

85 "A mencionada novidade possui um notável impacto prático na medida em que, sob a égide do CPC/1973, havia jurisprudência tranquila no sentido de que os tribunais não poderiam praticar atos de instrução do processo" (DANTAS, Bruno. Comentários ao art. 939. Comentários ao Código de Processo Civil. Cassio Scarpinella Bueno (coord.). São Paulo: Saraiva, 2017, p. 81).

86 Além disso, há quem enxergue um problema de efeito devolutivo, pois não haveria a devolução da questão probatória, pelos limites horizontais: REICHELT, Luis Alberto. Sistemática recursal, direito ao processo justo e o novo Código de Processo Civil: os desafios deixados pelo legislador ao intérprete. Revista de Processo. São Paulo: RT, v. 244, 2015, p. 21-22. O autor conclui pela possibilidade de prova diante de regra expressa. No entanto, é equivocada a afirmação de existir um entrave decorrente do efeito devolutivo, já que as questões probatórias não configuram capítulos decisórios, mas questões, abarcadas pelo efeito devolutivo vertical, ou em profundidade. 
Quanto ao primeiro argumento, ele parece pressupor que o tribunal é ontologicamente diferente do juiz de primeiro grau, como se não fosse - o tribunal e os seus órgãos julgadores -, também, um conjunto de juízes, que podem muito bem - normalmente com melhor estrutura do que aquela ao dispor dos juízes de primeiro grau - determinar a realização de provas. Não há qualquer inviabilidade essencial ou prática em realizar procedimentos probatórios, que devem ser conduzidos pelo juiz relator do processo (art. 932, I, CPC). Além disso, há a possibilidade de, por meio de carta de ordem, determinar-se que o juiz de primeiro grau conduza a produção de prova incidentalmente a procedimento no tribunal.

Sobre o argumento do custo temporal, o direito à prova é um direito fundamental associado ao direito de acesso à justiça e ao direito de participação, que simplesmente não pode ser suprimido por custar tempo. O fato de o argumento ser suscitado apenas quanto à produção de provas no tribunal, e nada falar acerca dos custos da prova no juízo de primeiro grau, ou quanto a tantos outros atos processuais que servem para preservar garantias fundamentais processuais, conota a falsidade de sua premissa e a sua inconsistência. Produzir provas preserva o direito de participação, isto é, de tentar convencer o órgão judicial detentor do poder de decisão a resolver o conflito de acordo com o que a parte entende ser o justo, pelo que cogitar a impossibilidade de produção de provas soa tão absurdo quanto a vedação à fala em si - afinal, a prova serve para convencer quanto à questão fática do mesmo modo que a argumentação jurídica serve para o convencer quanto à questão de direito. Assim como não se cogita eliminar a possibilidade de falar nos autos ou o dever de motivação por gerarem custo temporal, não se deveria suscitar esse problema na produção de provas pelo tribunal. ${ }^{87}$

Além disso, os tribunais têm competências originárias, o que significa que, nesses processos, eles podem precisar conduzir a instrução. Nos processos de competência originária, o tribunal é o responsável pela condução processual desde o seu início, o que inclui a fase probatória. Assim sendo, fica claro que não há obstáculo essencial a proibir a produção de provas no tribunal que, inequivocamente, faz exatamente isso nos procedimentos nele originados.

Por esses vários argumentos, insta concluir que a vedação tout court à produção de provas nos recursos é arbitrária e injustificada.

Destaque-se que tal problema não é tipicamente brasileiro. Em outros sistemas jurídicos já houve semelhante perplexidade com a produção de provas nos tribunais. Por exemplo, no direito italiano já se afirmou que a máxima é que os poderes do órgão judicial responsável pelo recurso são idênticos àqueles do juiz de primeiro grau, com exceção dos poderes instrutórios, que faltariam ao juiz do recurso. ${ }^{88}$ Todavia, ainda assim, quando cabível aportar novos fatos no juízo recursal, é inegável a possibilidade, indissociável, de produzir provas, que são realizadas sem quaisquer problemas no tribunal. ${ }^{89} \mathrm{Na}$ verdade, o próprio Codice di Procedura Civile, no art. 356, prevê o poder instrutório do juiz da apelação, ao ensejo de seu poder-dever de determinar a renovação total ou parcial das provas realizadas em primeiro grau; poder instrutório este que, segundo a doutrina, pode ser usado livremente, isto é, com a mesma mobilidade que tem o juiz de primeiro grau. ${ }^{90}$

Atualmente, no entanto, o próprio texto legal cuidou de exterminar esse absurdo, tornando insustentável qualquer razão no sentido de proibir provas nos tribunais - a lógica não fora suficiente para derrubar a inconsistência, mas a lei foi eficiente neste ponto. ${ }^{91}$ Realmente, diante da atribuição

87 "Por vezes, a eficiência processual determina a escolha do meio menos rápido ou célere para que as finalidades do processo sejam mais bem alcançadas dessa forma" (CAMPOS, Eduardo Luiz Cavalcanti. O princípio da eficiência no processo civil brasileiro. Rio de Janeiro: Forense, 2018, p. 67). O autor, partindo do exemplo da intervenção de terceiros, arremata que: “(...) em grande parte dos casos, o processo é mais eficiente para a promoção dos fins desejados se for admitida a intervenção, ainda que isso atrase a conclusão do processo”.

88 LUISO, Francesco Paolo. Appello. Digesto delle discipline privatistiche. Torino: UTET, 1998 (reimpressão da edição de 1987), p. 378-379.

89 Desenvolve raciocínio similar no direito italiano: LUISO, Francesco Paolo. Diritto processuale civile, II, cit., p. $396-397$. O mesmo processualista, ainda, destaca casos em que a produção de provas em tribunal é essencial, cf. p. 406-407.

90 MONTELEONE, Girolamo. Diritto processuale civile, II, cit., p. 621.

91 Chega-se a apontar uma "mudança de paradigma” com a permissão probatória: FARIA, Márcio Carvalho. O novo Código de Processo Civil vs. A jurisprudência defensiva. Coleção novo CPC: Doutrina Selecionada - Processo nos tribunais e meios 
outorgada ao relator para conduzir a instrução (art. 932, I, CPC), bem como da redação do art. 938, § 3o, do CPC/2015, não há qualquer espaço para a antiquada visão de que é impossível a produção de provas no tribunal. ${ }^{92}$

Desse modo, se, no julgamento do recurso, o tribunal perceber que alguma prova foi indeferida equivocadamente ou, com base no seu poder instrutório, entender que mais alguma prova é relevante para o deslinde mais preciso das questões fáticas, a lei processual lhe franqueia ordenar a produção. ${ }^{93}$ Inclusive, não há limitações para o meio de prova: pode ser inspeção judicial, perícia, oitiva de testemunha, depoimento pessoal da parte, etc. No ponto, aplicam-se as regras sobre provas, que se encontram no Livro dedicado ao procedimento comum, mas constituem verdadeiras regras gerais a disciplinar a produção de provas em qualquer tipo de procedimento.

Enfim, é possível a produção de provas no tribunal.

Cumpre fazer alguns esclarecimentos sobre a admissibilidade da prova, no entanto. É que, o fato de ser viável a produção probatória não quer dizer que ela será sempre permitida, por uma razão evidente: o sistema de preclusões. Cumpre enfatizar: as partes não podem, a qualquer tempo, requerer a produção probatória, ignorando o momento processual adequado para isso. Uma vez derrotada a parte, inclusive com base na regra do ônus da prova, não pode ela recorrer inovando nos seus requerimentos probatórios, arrependida de sua atuação negligente em primeiro grau.

A admissão de novas provas se dará nas hipóteses de recurso fundado em fato novo ou superveniente suscitado e admitido, ou quando o próprio recurso de apelação for fundado na inadequada inadmissão de prova (art. 1.009, $\S 1^{\circ}$ ) ou, possivelmente, quando for acolhida uma questão prejudicial ou preliminar de mérito, que reste superada no apelo e, ao prosseguir na decisão de mérito, perceba-se que falta a produção de uma prova. É possível, ainda, a produção de novas provas nos casos em que o relator ou o próprio colegiado reputem relevante para o deslinde da controvérsia a produção de alguma prova que não foi realizada em primeiro grau, fazendo uso de seu poder instrutório. ${ }^{94}$ Pode-se pensar, também, na determinação da renovação de uma prova, quando a sua conclusão não tenha sido clara ou mesmo se a forma como foi produzida assim recomende..$^{55}$

\section{Possibilidade de Correção de Vícios no Tribunal}

O CPC/2015 adotou o princípio da primazia do mérito, como um mecanismo normativo para reforçar a instrumentalidade das formas. Com isso, pretende que se priorize a decisão de mérito, o que inclui, naturalmente, a decisão de mérito do recurso. O propósito é extrair do processo, inclusive dos recursos, o seu máximo rendimento. ${ }^{96}$

Para sua concretização, nos recursos, são duas as possibilidades.

Primeiro, busca-se superar a chamada jurisprudência defensiva, o que é realizado mediante regras que permitem que sejam sanados vícios de admissibilidade do recurso, com a finalidade de evitar uma decisão terminativa. A norma pretendeu enfrentar uma postura infelizmente recorrente nos tribunais de fulminar os recursos por vícios de admissibilidade, quando seria totalmente viável a

de impugnação às decisões judiciais. Lucas Buril de Macêdo; Ravi Peixoto; Alexandre Freire (org.). 2ª ed. Salvador: Juspodivm, 2016 , p. 582.

92 Admitindo a produção probatória: MARANHÃO, Clayton. Da ordem dos processos nos tribunais. Aspectos polêmicos dos recursos cíveis e assuntos afins. São Paulo: RT, 2017, v. 13, p. 82-84.

93 No mesmo sentido: JORGE, Flávio Cheim. Teoria geral dos recursos cíveis, cit., p. 386. DIDIER JR, Fredie; CUNHA, Leonardo Carneiro da. Curso de direito processual civil, v. 3, cit., p. 46-47.

94 De modo idêntico, no direito italiano: MONTELEONE, Girolamo. Diritto processuale civile, II, cit., p. 622.

95 RICCI, Gian Franco. Diritto processuale civile. $6^{\mathrm{a}}$ ed. Torino: Giappichelli, 2017, v. II ${ }^{\mathrm{o}}$, p. 254;

96 ARRUDA ALVIM, Teresa. Recursos como uma forma de fazer "render" o processo no Projeto 166/2010. Revista de Processo. São Paulo: RT, 2010, n. 189, p. 276. 
sua correção, e notadamente como uma forma de redução do acervo, mesmo que barbárica e absurda. ${ }^{97}$ Assim, por exemplo, prevê o art. 932, parágrafo único, do CPC, que deve o relator intimar o recorrente para, no prazo de 5 (cinco) dias, ajustar o seu recurso quando verificar existir um defeito sanável, dentre outras várias previsões. ${ }^{98}$

Segundo, e mais interessante, o CPC buscou priorizar a decisão do mérito do processo, inclusive em sede recursal. Isso significa que, havendo uma decisão em primeiro grau que não resolveu o mérito, a lei processual permite que o tribunal o decida diretamente. Significa também que, existindo um vício que obste a análise do objeto recursal, alegado pelo recorrente ou pelo recorrido, ou um vício que em tese ensejaria a nulificação do processo, o tribunal poderá, reconhecendo a sua existência, utilizar de meios para resolver o ilícito processual que o gerou e, ato contínuo, resolver o mérito do recurso ou do processo..$^{99}$

Esta última hipótese é uma extensão considerável da possibilidade de correção de vícios nos tribunais.

Para que seja devidamente analisada, cumpre examinar a redação legal:100

Art. 938. A questão preliminar suscitada no julgamento será decidida antes do mérito, deste não se conhecendo caso seja incompatível com a decisão.

$\S 1^{\circ}$ Constatada a ocorrência de vício sanável, inclusive aquele que possa ser conhecido de ofício, o relator determinará a realização ou a renovação do ato processual, no próprio tribunal ou em primeiro grau de jurisdição, intimadas as partes.

$\S 2^{\circ}$ Cumprida a diligência de que trata o $\$ 1^{\circ}$, o relator, sempre que possível, prosseguirá no julgamento do recurso.

§ 3ํㅡㄹ Reconhecida a necessidade de produção de prova, o relator converterá o julgamento em diligência, que se realizará no tribunal ou em primeiro grau de jurisdição, decidindo-se o recurso após a conclusão da instrução.

$\S 4^{\circ}$ Quando não determinadas pelo relator, as providências indicadas nos $\S \S 1^{\circ}$ e $3^{\circ}$ poderão ser determinadas pelo órgão competente para julgamento do recurso.

Imagine-se, exemplificativamente, um caso de responsabilidade civil decorrente de um acidente com automóveis que foi julgado improcedente por falta de provas. No decorrer do processo, o réu pediu a produção de prova testemunhal, em tese capaz de demonstrar a culpa concorrente do autor e, também, a determinação de exibição de documentos em face de órgão público de segurança, que colheu o depoimento das pessoas envolvidas no dia do acidente, o que seria capaz de demonstrar a diminuta extensão do dano. Tais provas foram indeferidas, o que vem a ser objeto de impugnação em contrarrazões. No recurso do autor, o tribunal, ao dar provimento para julgar procedente o seu pedido, terá de analisar a impugnação subordinada em contrarrazões. No caso, para respeitar o direito à prova do réu, o tribunal teria de, a princípio, anular a sentença e determinar que o magistrado a quo produza as provas, julgue novamente, para que possivelmente viesse a reexaminar o mérito. Todavia, com a

97 De modo semelhante: CARMONA, Carlos Alberto. O sistema recursal brasileiro: breve análise crítica. Aspectos polêmicos e atuais dos recursos. Eduardo Pellegrini de Arruda Alvim; Nelson Nery Jr.; Teresa Arruda Alvim (coord.). São Paulo: RT, 2000, p. 45-47.

98 "Assim, cabe destacar que a regra do $\S$ único do art. 932 do CPC impõe uma nova racionalidade em prol do aproveitamento do recurso interposto, com o objetivo velado (ou, quiçá expresso) de suplantar certas práticas que, sob a vigência do CPC de 1973, eram enquadráveis como hipóteses de jurisprudência defensiva (para alguns, jurisprudência ofensiva) e que resultavam na inadmissibilidade de inúmeros recursos ordinários e extraordinários. Tem-se, então, verdadeira normatização contrafática, com vistas a coibir os padrões decisórios que buscavam tão-somente descongestionar os Tribunais" (KOZIKOSKI, Sandro Marcelo. Sistema recursal. Salvador: Juspodivm, 2016, p. 69). Sobre o princípio, e também sobre várias regras que o concretizam, conferir: OLIVEIRA, Pedro Miranda de. Apontamentos sobre o novíssimo sistema recursal. Revista de Processo. São Paulo: RT, v. 250, 2015, p. 271-285.

99 Destacando a prioridade da decisão de mérito nos recursos: BARBOSA MOREIRA, José Carlos. Restrições ilegítimas ao conhecimento dos recursos. Temas de direito processual (Nona série). São Paulo: Saraiva, 2007, p. 269-270.

100 A previsão de correção de vícios em apelação já havia sido incluída no CPC/1973, mediante a Lei 11.276/2006, que criou o $\$ 4^{\mathrm{o}}$ do art. 515 . 
permissão do art. 938, $\S 1^{\circ}$ e $§ 3^{\circ}$, pode o órgão julgador determinar a produção da prova e, em seguida, prosseguir no julgamento do recurso. ${ }^{101}$

Outro exemplo: em recurso se cumula pedido de reforma, alegando erro na solução de questões fáticas e jurídicas, e de anulação da decisão, este baseado na falta de intimação da parte para se manifestar quanto a documento juntado posteriormente pela parte adversa. Pode o relator, simplesmente, abrir prazo para que a parte se manifeste quanto à documentação e, com isso, resolver o pedido de decretação de nulidade e se concentrar no mérito do processo.

Esta leitura do dispositivo é manifestamente ampliativa, porém defensável com base no princípio da primazia do julgamento do mérito. ${ }^{102}$ É que o dispositivo, no caput, menciona que a questão conste como preliminar, pelo que, lidos os parágrafos de acordo com esse conteúdo, não seria possível a correção do vício quando ele for, justamente, o objeto do recurso. Logo, segundo essa visão restritiva, a questão que figure como preliminar do recurso é que é passível de correção, e não aquela atinente ao seu mérito. ${ }^{103}$

Esse, no entanto, não parece um óbice definitivo. Na verdade, o art. 938 emprega "preliminar" em sentido amplo, com referência ao mérito do processo. Sob essa perspectiva, toda questão relativa à nulidade de um ato processual será prelimitar ao mérito - não do recurso, mas do processo. De modo que, mesmo que o mérito do recurso seja a nulificação do processo por algum error in procedendo, tal equívoco no cumprimento de norma processual não deixa de ser uma questão preliminar ao mérito do processo, pelo que aplicável a previsão sanatória do art. 938 do CPC.

Mais ainda: é preciso dar máxima eficiência ao recurso civil (art. $8^{\circ}$ do CPC). ${ }^{104}$ Não se pode limitar o grau recursal a uma anulação para que, proferida outra decisão, venha ela novamente a figurar em apelação. Como meio de gerar economia de atividade estatal e duração razoável para as partes, o vício deve ser corrigido imediatamente e, ato contínuo, o tribunal prosseguir no julgamento. Essa é uma tendência no direito processual diante de sua inegável qualidade: evitar prejuízos às partes e ao Estado-juiz. ${ }^{105}$

101 Há quem interprete a regra, injustificadamente, de modo restritivo, entendendo que, se o juiz a quo indeferiu prova, o processo precisa ser anulado: QUEIROZ, Pedro Gomes de. A apelação no CPC/2015. Revista de Processo. São Paulo: RT, v. 260, 2016, p. 177. No sistema anterior, havia quem defendesse a inaplicabilidade da sanação de vícios em recurso quando houvesse a necessidade de produção de provas: ELIAS, Carlos Eduardo Stefen. Apelação - Os limites objetivos do efeito devolutivo. São Paulo: Atlas, 2010, p. 102-103. Todavia, com a atual redação legal, sobretudo com o $\$ 3^{\circ}$ do art. 938, o óbice não tem mais razão de ser.

102 Defendendo, com razão, uma interpretação ampliativa mesmo no sistema processual anterior: "Sempre que possível, deve ser evitada a antiga solução consubstanciada na mera cassação da sentença, com a simples determinação de retorno dos autos à Justiça de origem, para a morosa correção do vício pelo juiz de primeiro grau, com a posterior prolação de nova sentença, impugnável mediante outra apelação, dependente de novo preparo. A solução proveniente do $\$ 4^{\circ}$ deve ser prestigiada sempre que possível, por ser verdadeira garantia constitucional do jurisdicionado (artigo $5^{\circ}$, inciso LXXVIII, da Constituição Federal, acrescentado pela Emenda Constitucional n. 45 de 2004)" (SOUZA, Bernardo Pimentel. Introdução aos recursos cíveis e à ação rescisória, cit., p. 387). Similarmente: SILVA, Márcio Henriques Mendes da. Tentativa de sistematização do efeito devolutivo dos recursos. Aspectos polêmicos e atuais dos recursos cíveis. Nelson Nery e Teresa Arruda Alvim (coord.). São Paulo: RT, 2007, v. 11, p. 230.

103 Essa é a posição adotada em: ARAÚJO, Luciano Vianna. Apelação no Código de Processo Civil 2015. Revista de Processo. São Paulo: RT, v. 261, 2016, p. 288-289. Sobre a correção de vícios que ensejam a inadmissibilidade dos recursos, conferir, com muito proveito: JORGE, Flávio Cheim; SIQUEIRA, Thiago Ferreira. A sanabilidade dos requisitos de admissibilidade dos recursos: notas sobre o art. 932, parágrafo único, do CPC/15. Coleção novo CPC: Doutrina Selecionada - Processo nos tribunais e meios de impugnação às decisões judiciais. Lucas Buril de Macêdo; Ravi Peixoto; Alexandre Freire (org.). 2ª ed. Salvador: Juspodivm, 2016, p. 615-643.

104 "Em toda atividade estatal de criação de normas jurídicas, sejam atividades legislativas, jurisdicionais ou administrativas, sejam as normas gerais ou individuais, o Estado deve, ao mesmo tempo, respeitar o decido processo legal e agir de modo eficiente" (CAMPOS, Eduardo Luiz Cavalcanti. O princípio da eficiência no processo civil brasileiro. cit., p. 39).

105 Nesse sentido, já se afirmou há muito: "He señalado y ala evolución, que aún sigue, em cuanto a las vías para obtener la declaración de nulidad de las resoluciones judiciales, especialmente de las sentencias, y del equilibrio que debe buscarse entre justicia y seguridad jurídica. La anulación u con mayor fuerza la nulidad por vía de acción, perjudican la estabilidad e las resoluciones judiciales, dejando en sombras el fin justicia. Por eso la tendencia moderna es reparar los errores de procedimiento en la misma instancia y, cuando ello no sea posible, englobarlos en el recurso de apelación que busca la justicia del caso" (PODETTI, J. Ramiro. Tratado de los recursos. Buenos Aires: EDIAR, 1958, p. 25). 
Portanto, é possível corrigir nulidades processuais mesmo quando o próprio objeto do recurso for a anulação do processo. Nesse caso, o órgão judicante deverá promover a sanação do vício e, em seguida, com base no novo material, decidir o próprio objeto do processo. ${ }^{106}$

Essa interpretação permite que muitíssimos casos de alegação de error in procedendo convertam-se em nova decisão do mérito do processo. E isso por uma razão muito simples: basicamente todos os vícios processuais são sanáveis. ${ }^{107}$

Uma das funções primordiais do processo é a aplicação do direito material, que deve ser cumprida em observância das regras do devido processo legal e em respeito ao direito de participação dos litigantes. É para isso que se estruturam as regras processuais, e as nulidades são sanções que servem para penalizar o descumprimento das garantias das partes, encartadas em formas processuais. Quando o resultado a que serve a forma processual for alcançado, sem prejuízo às garantias, é que se dá aplicação à instrumentalidade: não se justifica a nulificação dos atos processuais praticados, ainda que preteridas certas formalidades. ${ }^{108}$

Assim, antes de aplicar a norma do art. 938, cumpre inicialmente examinar se a finalidade da forma processual foi alcançada. Se sim, não há nulidade ou vício a ser sanado. ${ }^{109}$ Nesse caso, a correção do ato é desnecessária, pois ele alcançou a sua finalidade. ${ }^{110} \mathrm{O}$ mesmo se diga quanto às nulidades que se convalidaram por não terem sido alegadas na primeira oportunidade. ${ }^{111}$

Todavia, caso seja necessário tutelar a garantia processual ensejadora da nulidade, o CPC permite a prática do ato processual em sede de apelação, extirpando a nulificação. Há o reconhecimento da nulidade, porém sem a efetiva decretação de nulidade dos atos processuais e todos os custos que isso acarretaria ao processo. ${ }^{112}$

Note-se que a conjunção dos $\$ \S 1^{\circ}$ e $3^{\circ}$ do art. 938 é salutar. Com a previsão dessas regras no mesmo dispositivo legal, justamente o que consagra a utilização do recurso como mecanismo de saneamento, tem-se um bom material argumentativo contra entendimentos limitadores do alcance da norma. A doutrina costuma enxergar como uma barreira a necessidade de produção de provas, seja ao saneamento do processo ou ao avanço sobre seu mérito. Por isso, o benfazejo $§ 3^{\underline{o}}$ evita que esse modo de compreender apequene a atividade saneadora em sede recursal.

No procedimento recursal em que o vício processual foi suscitado, pleiteando a anulação do processo, permite-se a imediata correção da falha processual, de modo a proteger o valor tutelado pela norma processual e, com isso, já garantir a tutela de outra importante função processual: a primazia da resolução do mérito e a duração razoável do processo. Preenche-se, no próprio procedimento recursal,

106 Em sentido contrário, ao analisar a regra no CPC/1973: BARIONI, Rodrigo. Efeito devolutivo da apelação, cit., p. 182. Também em sentido contrário, entendendo que não se pode aplicar a norma quando se tratar de vício na própria sentença ou que a eive de nulidade: JORGE, Flávio Cheim. Teoria geral dos recursos cíveis, cit., p. 377. Igualmente: Em sentido contrário, por todos: ARRUDA ALVIM, Teresa. Nulidades do processo e da sentença, cit., p. 257. Esta última posição acaba por reduzir a aplicabilidade da norma a praticamente quase nada, já que as nulidades processuais no primeiro grau tendencialmente afetam a sentença, pois este é o ato processual fim do procedimento como um todo, e que os atos processuais nulos inquinam os consequentes (art. 281 do CPC).

107 BEDAQUE, José Roberto dos Santos. Nulidades processuais e apelação. Meios de impugnação ao julgado civil - Estudos em homenagem a José Carlos Barbosa Moreira. Adroaldo Furtado Fabrício (coord.). Rio de Janeiro: Forense, 2007, p. 404.

108 BEDAQUE, José Roberto dos Santos. Nulidades processuais e apelação, cit., p. 408-413.

109 "É preciso muito cuidado para não nos deixarmos levar pela solução mais cômoda. Verificada a nulidade, sem qualquer consideração quanto ao escopo do ato viciado, determina-se a renovação. Essa opção é mais simples, menos trabalhosa, mas não é a melhor. Só deve ser adotada se não alcançado o objetivo previsto para o ato. Caso inexista prejuízo para o escopo pretendido pelo legislador com a formalidade, a convalidação se dá independentemente de qualquer diligência. Basta aplica o princípio da instrumentalidade das formas" (BEDAQUE, José Roberto dos Santos. Nulidades processuais e apelação, cit., p. 415).

110 BERNINI, Enrico. L'istruzione e la decisione. Il nuovo appello civile. Claudio Cecchella (dir.). Torino: Zanichelli, 2017, p. 185.

111 ARRUDA ALVIM, Teresa. Nulidades do processo e da sentença, cit., p. 256.

112 Em sentido contrário, afirmando que se se tratar de nulidade absoluta deve ser anulada a sentença ou o processo e remetido ao juízo a quo: OLIVEIRA, Gleydson Kleber Lopes de. Apelação no direito processual civil, cit., p. 205. 
o requisito do qual a condução anterior do processo havia prescindido para permitir que uma nova decisão de mérito, desta vez válida e legítima, seja proferida.

Coloca-se o procedimento recursal também no eixo da função do processo: ele serve para a resolução jurisdicional da controvérsia a partir de um procedimento em respeito - inclusive e sobretudo - aos direitos fundamentais processuais das partes. ${ }^{113} \mathrm{E}$, de modo mais específico, o recurso torna-se um mecanismo adequado para sanar vícios processuais, corrigindo erros cometidos pelo juízo de primeiro grau. ${ }^{114}$

Portanto, o instituto da correção de vícios possui duas funções: a estrita, decorrente da leitura dos parágrafos do art. 938 do CPC presos ao caput, que permite superar as preliminares recursais mediante atividade saneadora; e a ampla e mais rica, destacada acima, que permite a sanação de vícios processuais ocorridos no primeiro grau, mesmo que na sentença e inclusive quando forem objeto do recurso, o que tornará viável o imediato julgamento do mérito.

No que se refere ao objeto do juízo recursal, a norma permite um desvio procedimental, que certamente traz novo material a ser conhecido pelo julgador, e que permitirá ou a redução do objeto, no caso de se tornar prejudicado o pedido de anulação, ou, mais ainda, a sua alteração: no caso de o recorrente requerer a anulação da decisão, o tribunal, após sanar o vício invocado (como no caso de produzir a prova indeferida ou de permitir a manifestação da parte quanto a material que não havia sido submetido ao contraditório), deve reanalisar o mérito do processo à luz do novo material, seja a prova ou a nova manifestação da parte. Há, portanto, a alteração do objeto recursal: a parte argui existir um vício no procedimento e requer a anulação da decisão e, além de ver o vício ser sanado, recebe nova decisão de mérito.

Trata-se, portanto, de uma ampla possibilidade de alteração do objeto recursal, porém sempre alinhada com a diretriz de primazia do julgamento do mérito e de duração razoável do processo, o que tem potencial de reduzir acentuadamente as hipóteses de anulação de decisão por error in procedendo. A partir da aplicação do art. 938 do CPC, especialmente em uma visão que priorize o julgamento do mérito, há uma tendência à efetiva redução de provimentos de anulação de decisão, que serão cambiados por um procedimento de correção de vício seguido de uma nova decisão de mérito. Sendo potencializada a sua aplicação, pode-se até mesmo vislumbrar um cenário em que ocorrerá a total extinção das anulações de decisões como resultado de recursos cíveis, já que as impugnações servirão para a correção do vício no próprio procedimento recursal e, consequentemente, para a prolação de nova decisão de mérito.

\section{Ampliação do Julgamento do Mérito em Sede Recursal - Arremate}

O recurso pode suscitar uma causa de nulidade do processo ou da sentença, e veicular pretensão à anulação da decisão ou de parcela do procedimento. Portanto pode ser pedida no recurso a aplicação do efeito típico da nulidade. Por isso, é lídimo concluir que o recurso constitui relevantíssimo mecanismo de controle da condução do processo pelo Estado-juiz, ou seja, controle sobre a produção dos pronunciamentos judiciais em que se distribui a justiça. ${ }^{115}$

Aqui, é importante a tradicional diferenciação entre o iudicium rescindens e o iudicium rescissorium, que compõem o julgamento do mérito dos recursos. O primeiro diz respeito ao desfazimento da decisão impugnada, enquanto o segundo à prolação de uma nova decisão, que substitua aquela objeto de

113 FARIA, Márcio Carvalho. O novo Código de Processo Civil vs. A jurisprudência defensiva. Coleção novo CPC: Doutrina Selecionada - Processo nos tribunais e meios de impugnação às decisões judiciais. Lucas Buril de Macêdo; Ravi Peixoto; Alexandre Freire (org.). 2ª ed. Salvador: Juspodivm, 2016, p. 568.

114 Algo similar ocorreu na Itália: "Il nostro legislatore, gradualmente (e ciò se coglie bene nel passagio dal vecchio al nuovo codice), ha reso il processo di appello idoneo a correggere quasi tutti gli errori processuali che si sono verificati nel processo di primo grado. L'appello, quindi, è un mezzo di controllo, ma anche di recupero dei vizi (naturalmente sanabili) verificatasi in primo grado" (LUISO, Francesco Paolo. Diritto processuale civile, II, cit., p. 415).

115 Já defendia essa aproximação, embora com foco na admissibilidade recursal: DIDIER JR, Fredie. Pressupostos processuais e condições da ação: o juizo de admissibilidade do processo. São Paulo: Saraiva, 2005, p. 37-40. 
impugnação. No direito italiano, por exemplo, a diferença mostrava-se sobremaneira útil para distinguir o appello, meio de gravame em que se reexaminava a causa, e o ricorso per cassazione, em que apenas se cassava a decisão impugnada e remetia-se a tomada de nova decisão para órgão judicial a quo (giudizio di rinvio).

Porém, é também comum apontar que referida distinção perde prestígio nos ordenamentos processuais contemporâneos, sobretudo porque os meios de impugnação assumem, no mais das vezes, ambos os juízos, e eles são proferidos simultaneamente, sem solução cronológica ou repartição em diversos atos processuais. Isso torna os dois juízos, rescindente e rescisório, "invisíveis" ou, ao menos, eles acabam mesclados no mesmo ato decisório. Isso porque, normalmente, é a mesma decisão judicial que realiza a anulação da decisão anterior, por sua ilegalidade, que promove a substituição dela por uma nova em conformidade com o ordenamento jurídico. É isso que ocorre nos recursos especial e extraordinário no ordenamento processual brasileiro, e foi isso que passou a ser a regra na cassazione italiana. Percebe-se, enfim, que a tendência no direito recursal é a homogeneização pragmática do iudicium rescindens com o iudicium rescissorium. ${ }^{116}$

Sobre esse movimento, Barbosa Moreira destacou, argutamente, uma hipótese em que ambos os juízos são bem distinguíveis: no recurso fundado em error in procedendo. Nesse caso, invocando o erro de cunho processual, a parte impugna aspecto do procedimento ou da decisão que foi malconduzido, merecendo, por isso, anulação para que seja feito novamente, agora de modo correto. Pede, simplesmente, que o tribunal anule a decisão. Daí, conclui-se que, "se o órgão ad quem dá provimento à apelação, limita-se a cassar a sentença". ${ }^{117}$

Toda essa construção, na esfera recursal, tem suporte na já examinada diferenciação entre error in procedendo e error in judicando.

É preciso reconhecer, porém, que a diferença entre as duas categorias perdeu muito de sua relevância, vez que os recursos passaram a ser mecanismos adequados para a tutela contra todas as ilicitudes das decisões judiciais. Antes, como já se destacou, os errores in procedendo serviam para meios impugnativos próprios, especialmente a famosa querela nullitatis, que, porém, foi absorvida pela impugnação via recurso. A partir dessa mudança, tornou-se muito menos importante diferenciar os dois.

Parece que, se se colocam as coisas em perspectiva histórica, há um maior prestígio dos erros procedimentais. Perceba que a nulidade da sentença não se submetia a um prazo ou à preclusão, enquanto o remédio para o combate da injustiça tinha um prazo certo, e, caso escoado, a coisa julgada passava a impedir que a matéria fosse rediscutida. Do ponto de vista axiológico, fica claro que, nesse quadrante histórico, o sistema jurídico reputava um vício procedimental muito mais grave do que um de natureza substancial; preferia-se abrir mão da maior segurança jurídica na estruturação das impugnações aos vícios procedimentais, o que se fazia ao se permitir impugná-los mediante um remédio imune à preclusão, enquanto a coisa julgada, como medida de segurança, fez-se presente e impedia a rediscussão de injustiças palpáveis.

Aliás, não é ocioso lembrar: é muito comum ver proposições teóricas, atuais ou não, que descrevem o error in iudicando como uma injustiça e, por outro lado, o error in procedendo como um ilícito. Naquele, a parte reclamaria de uma aplicação menos adequada da norma ou de seu prejuízo iníquo; neste, há o ferimento à lei, uma verdadeira agressão ao ordenamento jurídico. Essa perspectiva é um resquício inapropriado do passado, que sobrelevava o procedimento ao mérito, em uma inversão de valores insustentável no sistema positivo, em que se impõem a instrumentalidade das formas e a primazia do julgamento do mérito.

Os erros de julgamento são erros de aplicação do ordenamento jurídico. Há, neles também, ilícito. E essa perspectiva é essencial: o error in iudicando, antes ligado à categoria da injustiça, algo

116 Para uma crítica à cassação de decisões judiciais como resultado do recurso especial no direito brasileiro: CUNHA, Leonardo Carneiro da. A cassação e o superior tribunal de justiça brasileiro. Revista de processo. São Paulo: RT, v. 299, jan. 2020 .

117 BARbOSA MOREIRA, José Carlos. Comentários ao Código de Processo Civil, V, cit., p. 403. 
menos que o ilícito, não pode mais ser descrito da mesma maneira. ${ }^{118} \mathrm{O}$ ilícito no conteúdo da decisão é tão ou mais importante do que aquele que se apurou no desenrolar do processo ou na forma como se proferiu a decisão. A decisão que erra no julgamento ou parte de um juízo fático errôneo ou aplica de modo equivocado uma norma jurídica é ilícita e revela-se sobremaneira importante, inclusive porque é apta a se tornar imutável. ${ }^{119}$

Enfim, ambas as hipóteses - erro de julgamento e erro de procedimento - são, inegavelmente, ilícitos judiciais, que têm no recurso um mecanismo jurídico-racional de controle, de modo a funcionalizar a tutela do direito a decisões justas.

Isso, ademais, ganha força com a própria unificação de resultados dos recursos. Atualmente, como se viu, o julgamento imediato do mérito permite que recurso com propósito de anular a decisão recorrida enseje nova decisão de mérito.

Realmente, é preciso reconhecer que, no direito brasileiro atual, vê-se o crescimento de hipóteses nas quais, em vez de simplesmente anular o processo e remetê-lo ao juízo a quo para que reconduza a atividade processual, permite-se que se empreenda atividade para sanar os vícios no próprio tribunal. Com isso, protegem-se as partes e o Estado-juiz contra o dispêndio de energia e tempo com atividade processual e evitam-se custos processuais: torna, enfim, o processo mais eficiente.

Esse movimento, que não era visto com tanta simpatia, é totalmente condizente com uma visão de processo eficiente, capaz de entregar resultados com menores custos e em tempo razoável. Imaginese a hipótese na qual, instruído o processo e decidido no mérito, ele vem a ser anulado por falta de uma prova, determinando sua produção em primeiro grau, para posterior retorno ao tribunal, no qual, inclusive, outra nulidade, agora referente ao modo de produção da prova, pode vir a ser suscitada. Não há racionalidade nisso, visto que a multiplicação do gasto público é intolerável e o prejuízo às partes é injustificável.

Na verdade, vê-se no direito processual civil, já há bastante tempo, a paulatina e vagarosa desvalorização dos aspectos meramente formais do processo, o que se dá mediante o descortino das funções desenvolvidas pelos vários aspectos procedimentais e, a partir daí, o descarte de formas excessivas e desprovidas de funcionalidade. Ademais, quando não é esse o caso, prestigia-se a tutela da função desenvolvida pela forma, mesmo que isso se faça atipicamente. Há primazia da função essencial do processo: a tutela dos direitos em procedimento que assegure o respeito aos direitos fundamentais das partes. O que corrobora tais funções deve nortear a solução de problemas, inclusive os processuais.

No sistema recursal brasileiro, onde não raro os formalismos são exacerbados, e via-se um desprestígio da resolução do mérito, observa-se um real incentivo do CPC no sentido da mudança: buscase superar problemas processuais de duas ordens nos recursos. A uma, estatuiu-se a oportunização de correção dos vícios formais nos próprios recursos, sempre que for possível corrigi-los. A outra, e mais importante, possibilitou-se que os vícios no processo de primeiro grau passassem a ser corrigidos em grau recursal.

Assim é que o recurso se torna mecanismo de controle e, mais, de recuperação de vícios processuais - normalmente e naturalmente corrigíveis.

118 Propunha uma visão que diferenciava os vícios não essencialmente, mas em confronto com a impugnação, porém ainda colocando a nulidade como uma ilicitude e a injustiça mais como o requerimento de um novo juízo: CERINOCANOVA, Augusto. Le impugnazioni civili - struttura e funzione. Padova: CEDAM, 1973, p. 102-103.

119 "La verità è che all'origine dell'esposta dottrina - que divide erros de julgamento e de procedimento - sta un radicale equivoco, che è in definitiva lo stesso che ha portato a fissare come un dato razionale la distinzione o l'opposizione fra errores in judicando ed errores in procedendo. E l'equivoco sta nella scissione tra giudizio e processo, in quanto il giudizio viene riportato a un modello astratto, e quindi esterno al processo, di decisione giusta, con la conseguente impossibilità di configurare como 'vizio' l'ingiustizia della sentenza, che finisce col risolversi in una opinione o una valutazione soggettiva del giudice e della parte. Solo gli errori in procedendo costituirebbero in tal modo una violazione della legge (processuale), mentre gli errori in judicando non violerebbero alcuna legge, non sarebbero a rigor di termini, neppure errori, tanto che se la legge processuale non organizzasse dei mezzi speciali per la rinnovazione del giudizio (i famosi mezzi di gravami) l'ingiustizia della sentenza non avrebbe nessuna possibilità di essere rilevata” (SATTA, Salvatore. Le impugnazioni. Casa Editrice Dr. Francesco Vallardi, 1962, p. 10). 
Movimento nesse sentido ocorreu também na Itália. No codice de 1865, o juiz da apelação é quem deveria estipular se, detectado um vício no processo de primeiro grau, caberia a correção em sede recursal, com a renovação do ato viciado, ou a remessa do processo para o juízo a quo, de modo que lá se refizessem os atos viciados corretamente. Por sua vez, no c.p.c. de 1942, o art. 354 adotou a preferência expressa pela correção dos vícios do juízo de primeiro grau em sede de apelação. Deve o órgão judicial responsável pelo recurso, reconhecendo a nulidade de um ato processual, sempre que possível, renoválo ele mesmo e seguir para a decisão de mérito. ${ }^{120} \mathrm{O}$ próprio dispositivo normativo, somado com a hipótese do art. 353 do c.p.c., prevê uma lista de exceções (tida como taxativa): i) declaração de carência de jurisdição; ii) nulidade da citação; iii) falta de litisconsorte necessário; iv) declaração de exclusão equivocada de uma parte; v) inexistência da sentença de primeiro grau; vi) extinção do processo sem resolução do mérito reputada equivocada. Na doutrina já se suscita a exclusão dessa lista, de modo que se possibilite a ampliação e intensificação do movimento em favor da função corretiva do recurso. ${ }^{121}$

Perceba-se que, na Itália, os casos em que se conclui pela anulação da decisão recorrida são previstos taxativamente em lei (arts. 353 e 354 do c.p.c.), pelo que, a Corte de Cassação decidiu que, ${ }^{122}$ nos casos em que a apelação é interposta sem pedido de nova decisão de mérito, ou seja, apenas com pedido de anulação, ela é inadmissível se se tratar de hipótese em que não cabe a mera anulação. ${ }^{123}$

Com efeito, parece que a ampliação da possibilidade de decisão imediata do mérito em sede recursal tende a se expandir no direito processual brasileiro: conjugando o art. 1.013, $§ 3^{\circ}$, com os $\$ \S 1^{\circ}$ a $4^{\circ}$ do art. 938, dispositivos já examinados, seria possível que o órgão jurisdicional superior ingressasse no mérito diretamente em quase qualquer recurso. De fato, a partir de uma pequena reforma legislativa ou mesmo de uma interpretação sistemática ampliativa - que parece ser impulsionada pela eficácia interpretativa do princípio da primazia do mérito -, pode se tornar obsoleta a remessa do processo ao primeiro grau ou o uso do recurso com a finalidade de anulação, permitindo-se, em praticamente qualquer hipótese, que o vício detectado seja corrigido, inclusive mediante a produção de provas no tribunal, procedendo-se, ato contínuo, com a decisão de mérito da causa.

Não há qualquer óbice ontológico para isso. É, na verdade, o prosseguimento da tendência de se compreender que o duplo grau de jurisdição se satisfaz com duas prestações jurisdicionais, independentemente dos seus conteúdos, isto é, ele não se confunde com o duplo exame da mesma questão, que não é garantido. Isso significa a possibilidade de duas decisões sobre o mérito, porém sem assegurar que ambas as decisões versarão sobre ele. Tudo que é desenvolvido em primeiro grau pode ser feito pelo juízo de segundo grau. Não há qualquer entrave de ordem lógica ou operacional - até mesmo porque, como se viu, há a possibilidade de delegação de atos para o juízo de primeiro grau, porém com a conservação do poder de decisão do tribunal.

A finalidade do recurso deve ser a prolação de decisão capaz de corresponder ao provimento que deveria ter sido proferido pelo juízo a quo. ${ }^{124}$ Naturalmente, como a função proeminente do processo é a tutela dos direitos, esse provimento é, possivelmente, um provimento de mérito, a resolução com aptidão para se tornar definitiva do objeto do processo. Idealmente, portanto, assim como no primeiro grau, a decisão em grau recursal deve versar sempre que possível sobre o mérito do processo. Trata-se do vetor normativo estabelecido pelo princípio da primazia do mérito, que ganha densidade com as regras encartadas nos arts. 938 e 1.013, § $3^{\circ}$, do CPC, merecedoras de uma leitura conjunta e potencializadora do princípio.

Inclusive, essa tendência põe-se no eixo do sistema de nulidades, o que fica claro por uma perspectiva que parta da sentença (ou da sua absorção do vício indicado): renova-se o ato, agora validamente. Isto é, verificado um vício formal na sentença ou que a impinja, a diretiva é que o ato seja

120 PROTO PISANI, Andrea. Lezioni di diritto processuale civile, cit., p. 503. Assim também: LUISO, Francesco Paolo. Diritto processuale civile, II, cit., p. 415.

$121 \quad$ LUISO, Francesco Paolo. Diritto processuale civile, II, cit., p. 418.

122 Cassazione, Sezioni Unite, n. 10288, 27 luglio 2001.

123 Cf. DIANA, Antonio Gerardo. Le impugnazioni nel processo civile. Milano: Giuffrè, 2014, p. 16-17.

124 BALENA, Giampiero. Istituzioni di diritto processuale civile, v. II ${ }^{\underline{o}}$, cit., p. 416-417. 
renovado: pratica-se, em segundo grau, a renovação do ato viciado com a prolação de nova sentença, livre de vícios. Isso significa que o procedimento recursal, com o proferimento de nova decisão de mérito, nada mais é do que o procedimento para a renovação do ato nulo. ${ }^{125}$

Com a aplicação ampliativa do julgamento direto de mérito, especialmente nos casos em que a pretensão recursal era de nulificar a decisão ou o processo, há uma evidente ampliação do objeto do juízo recursal. Este, na verdade, é segmentado em fases: primeiro, atesta a ilicitude procedimental, que seria, em tese, merecedora de anulação; segundo, realiza-se um juízo de viabilidade da correção no tribunal, que é norteado pelo princípio da primazia do mérito - isto é, a correção deve ser realizada quando não prejudicar direito fundamental processual da parte -; terceiro, instaura-se o incidente de correção, com toda participação processual das partes e a prática dos atos saneadores; quarto, após tudo isso, decide-se o objeto do processo.

Nas fases delineadas, percebe-se que a primeira é equivalente ao juízo recursal. As demais fases são consequências do provimento do recurso. Percebe-se que, constatada a ilicitude, o tribunal passará a atribuir a consequência que reputa adequada a ela, que é a correção do vício processual e o proferimento da decisão de mérito. Portanto, verificada a ilicitude procedimental, o tribunal decide encaminhar o processo, perante si mesmo, para a solução do seu mérito. Essa é a conclusão do recurso. Na segunda, terceira e quarta fase delineadas acima, não há mais julgamento do recurso, que se esvaiu com o reconhecimento da ilicitude, mas o julgamento da própria demanda (do mérito do processo).

Essa solução parece mais adequada e de acordo com o princípio da primazia do mérito, por isso aplicável de lege lata.

Com isso, por exemplo, em vez de se limitar o tribunal a decretar a nulidade da sentença em que prova pericial foi ilicitamente inadmitida, seria possível ao tribunal: (i) reconhecer a nulidade da sentença, decretando-a; (ii) em vez de remeter o processo ao juízo a quo, determinar a produção da prova (art. 938, CPC), produzi-la, submetendo tudo ao contraditório; (iii) em seguida, prosseguir para o julgamento do mérito (art. 1.013, § $3^{\circ}$ ). Isto é, o tribunal pode, muito bem, trabalhar para deixar o processo em condições de julgamento e, em seguida, julgar o mérito do processo.

Outro exemplo: vê-se que a exigência de "processo maduro" resulta no entendimento de que a apelação contra "sentença de indeferimento liminar da petição inicial jamais enseja o imediato julgamento do mérito da causa”. ${ }^{126}$ Esse entendimento se dá porque, primeiro, as contrarrazões ao recurso não se confundem com a contestação, ${ }^{127} \mathrm{e}$, segundo, não poderia o tribunal converter o julgamento em diligência para que se oportunize a resposta à demanda. ${ }^{128}$

Porém, na doutrina, há entendimento em sentido contrário, que defende a possibilidade, mesmo nos casos de indeferimento ou de julgamento liminar pela improcedência, de decisão imediata do mérito pelo tribunal, desde que seja dada oportunidade ao réu de contestar a demanda e de que não seja necessária a produção de provas. ${ }^{129}$

125 LUISO, Francesco Paolo. Invalidità della sentenza e mezzi di gravame. Rivista di diritto processuale. Padova: CEDAM, v. LXIV, n. 1, 2009, p. 27-28.

126 SOUZA, Bernardo Pimentel. Introdução aos recursos cíveis e à ação rescisória. 5ª ed. São Paulo: Saraiva, 2008 , p. 374.

127 No sistema do CPC/1973, entendia que as contrarrazões contra o julgamento liminar pela improcedência tinham natureza de contestação: LIMA, Patrícia Carla de Deus. O julgamento da apelação do art. 285-A do CPC. Aspectos polêmicos e atuais dos recursos cíveis. Nelson Nery e Teresa Arruda Alvim (coord.). São Paulo: RT, 2007, v. 11, p. 279. Há quem entenda, ainda, que o recurso só terá natureza de contrarrazões se o réu assim optar: ELIAS, Carlos Eduardo Stefen. Apelação - Os limites objetivos do efeito devolutivo, cit., p. 117.

128 CAMBI, Eduardo. Questões recursais envolvendo a aplicação do art. 285-A do CPC. Aspectos polêmicos e atuais dos recursos cíveis. Nelson Nery e Teresa Arruda Alvim (coord.). São Paulo: RT, 2007, v. 11, p. 65-66. No mesmo sentido: MEDINA, José Miguel Garcia. A recentíssima reforma do sistema recursal brasileiro - análise das principais modificações introduzidas pela Lei 10.352/2001, e outras questões. Aspectos polêmicos e atuais dos recursos e de outros meios de impugnação às decisões judiciais. São Paulo: RT, 2002, v. 6, p. 346-347. Também entende inadequada a aplicação do dispositivo, porém sem considerar a possibilidade de conversão em diligência: SIQUEIRA, Thiago Ferreira. Duplo grau de jurisdição e "teoria da causa madura" no novo Código de Processo Civil, cit., p. 867.

129 "Porém, o simples fato de a demanda ter sido liminarmente julgada em primeira instância não inviabiliza o aprofundamento no exame das questões de mérito diretamente em segunda instância, inclusive para que ela seja considerada 
Esta última opção parece ser a mais acertada.

Frise-se: a diretriz é que, uma vez entregue a prestação jurisdicional, o retorno ao primeiro grau deve ser evitado, devendo a Corte resolver o mérito sempre que puder. O melhor, sobretudo sob a lente da eficiência e da celeridade, é evitar a descida do processo apenas para a tomada de uma decisão que muito provavelmente será impugnada para retornar, mais uma vez, ao tribunal. Basta respeitar a garantia fundamental do contraditório e, em seguida, proferir a decisão de mérito. $\mathrm{O}$ que, afinal, impede ou obsta o tribunal de dar um simples despacho intimando a parte para se defender e, em seguida, decidir o mérito? Não se encontra outra resposta senão uma visão excessivamente formalista e arraigada a antigos dogmas, pois, atualmente, é inegável que a parte não tem direito ao exame do mérito em dois graus. Trata-se, enfim, de uma providência simples, uma intimação para oferecer defesa, que é uma intimação como outra qualquer, algo que absolutamente não é estranho, e muito menos impossível ou mesmo dificultoso, ao procedimento em tribunal. Em seguida, não sendo necessária a tomada de providências (especialmente a do art. 350 do CPC), é só proceder com o julgamento da causa.

Consigne-se, por fim, que apesar de já parecer possível, de lege lata, uma interpretação ampliativa do art. 1.013, § 3o, CPC, combinando-o com o art. 938, CPC, o melhor, sem dúvidas, é uma reforma do dispositivo. A melhor solução é atribuir o poder ao tribunal de realizar diligências e de sanear vícios, reservando a devolução do processo para o juízo a quo nos casos mais complexos ou que exijam muitas diligências e, assim, a correção não se revele conveniente. O único limite intransponível para potencializar o julgamento imediato do mérito são os direitos fundamentais processuais das partes: quando o julgamento for causar prejuízo a eles, não é possível fazê-lo.

Nesse quadro, a anulação do processo como resultado dos recursos cíveis torna-se medida absolutamente excepcional. Podem, assim, ser julgadas pelos tribunais não apenas as causas maduras, mas aquelas que forem amadurecidas pela própria Corte.

\section{Referências}

APRIGLIANO, Ricardo de Carvalho. A apelação e seus efeitos. 2ª ed. São Paulo: Atlas, 2007.

ARAÚJO, Luciano Vianna. Apelação no Código de Processo Civil 2015. Revista de Processo. São Paulo: RT, v. 261, 2016.

ARRUDA ALVIM, Eduardo; ARRUDA ALVIM, Angélica; FERREIRA, Eduardo Aranha. Os efeitos devolutivo e translativo da apelação no CPC/2015. In: Nelson Nery Jr.; Teresa Arruda Alvim (coord.). Aspectos polêmicos dos recursos cíveis e assuntos afins, v. 13. São Paulo: RT, 2017. Nulidades do processo e da sentença. São Paulo: RT, 2019.

Recursos como uma forma de fazer "render" o processo no Projeto 166/2010. Revista de Processo. São Paulo: RT, 2010, n. 189.

ASSIS, Araken de. Manual dos recursos. 9ª ed. São Paulo: RT, 2017.

. Cumulação de ações. $4^{\mathrm{a}}$ ed. São Paulo: RT, 2002.

BALENA, Giampiero. Istituzioni di diritto processuale civile, v. II ${ }^{o}$, cit., p. 416-417.

BANDEIRA DE MELO, Ricardo Procópio. Princípio do duplo grau de jurisdição: garantia constitucional, extensão e alguma notas sobre o $\$ 3^{0}$ do art. 515 do CPC. Aspectos polêmicos e atuais dos recursos cíveis e de outros meios de impugnação às decisões judiciais. São Paulo: RT, 2005, v. 8.

procedente, com uma reviravolta no resultado do processo. Basta, repise-se, que nenhuma outra atividade seja necessária ao deslinde da causa" (BONDIOLI, Luís Guilherme Aidar. Comentários ao Código de Processo Civil, XX, cit., p. 113). Admite o julgamento direto no caso de improcedência liminar: DIDIER JR, Fredie; CUNHA, Leonardo Carneiro da. Curso de direito processual civil, v. 3, cit., p. 182-184. Admite a aplicação do julgamento direto, porém apenas se for para a rejeição do pedido do autor: ARRUDA ALVIM, Teresa. Nulidades do processo e da sentença, cit., p. 255. 
BARBOSA MOREIRA, José Carlos. Comentários ao Código de Processo Civil. $16^{\mathrm{a}}$ ed. Rio de Janeiro: Forense, v. 5, p. 230-232

Reformatio in peius (Processo Civil). Direito processual civil (ensaios e pareceres). Rio de Janeiro: Borsoi, 1971, p. 147

- Restrições ilegítimas ao conhecimento dos recursos. Temas de direito processual (Nona série). São Paulo: Saraiva, 2007.

BARIONI, Rodrigo. A proibição da reformatio in peius e o $§ 3^{\circ}$ do art. 515 do CPC. Aspectos polêmicos $e$ atuais dos recursos cíveis e de outros meios de impugnação às decisões judiciais. São Paulo: RT, 2005, v. 8, p. $715-716$

Efeito devolutivo da apelação. São Paulo: RT, 2008.

BEDAQUE, José Roberto dos Santos. Apelação: admissibilidade e efeitos. Aspectos polêmicos e atuais dos recursos cíveis e de outros meios de impugnação às decisões judiciais. Nelson Nery Jr. e Teresa Arruda Alvim (coord.). São Paulo: RT, v.7, 2003.

. Nulidades processuais e apelação. Meios de impugnação ao julgado civil - Estudos em homenagem a José Carlos Barbosa Moreira. Adroaldo Furtado Fabrício (coord.). Rio de Janeiro: Forense, 2007.

BERNINI, Enrico. L'istruzione e la decisione. Il nuovo appello civile. Claudio Cecchella (dir.). Torino: Zanichelli, 2017.

BRASIL. Supremo Tribunal Federal - Plenário, RHC 79.785-RJ, Rel. Min. SEPÚLVEDA PERTENCE, julgado em 29/03/2000, DJ 22/11/2002, p. 57

BOLZANI, Virginia Brodbeck. Efeito devolutivo da apelação. Rio de Janeiro: Aide, 2001.

BONDIOLI, Luis Guilherme Aidar. Comentários ao Código de Processo Civil. São Paulo: Saraiva, 2016, v. $\mathrm{XX}$.

CALAMANDREI, Piero. Appello. Opere giuridiche. Napoli: Morano, 1979, v. VIII.

. Sulla distinzione tra error in judicando ed error in procedendo. Opere giuridiche. Napoli: Morano, 1979, v. VIII.

CALMON DE PASSOS, José Joaquim. As razões da crise de nosso sistema recursal. Meios de impugnação ao julgado civil - Estudos em homenagem a José Carlos Barbosa Moreira. Adroaldo Furtado Fabrício (coord.). Rio de Janeiro: Forense, 2007.

CAMBI, Eduardo. Questões recursais envolvendo a aplicação do art. 285-A do CPC. Aspectos polêmicos e atuais dos recursos cíveis. Nelson Nery e Teresa Arruda Alvim (coord.). São Paulo: RT, 2007, v. 11.

CAMPOS, Eduardo Luiz Cavalcanti. O princípio da eficiência no processo civil brasileiro. Rio de Janeiro: Forense, 2018. 90,2016 Ato-fato processual: reconhecimento e consequências. Revista de Processo, v. 254, p. 75-

CAPPELLETTI, Mauro. Parere iconoclastico sulla riforma del processo civile. Giustizia e società. Milano: Edizione di Comunità, 1972.

CARMONA, Carlos Alberto. O sistema recursal brasileiro: breve análise crítica. Aspectos polêmicos e atuais dos recursos. Eduardo Pellegrini de Arruda Alvim; Nelson Nery Jr.; Teresa Arruda Alvim (coord.). São Paulo: RT, 2000.

CERINO-CANOVA, Augusto. Le impugnazioni civili - struttura e funzione. Padova: CEDAM, 1973.

DIANA, Antonio Gerardo. Le impugnazioni nel processo civile. Milano: Giuffrè, 2014.

CHIOVENDA, Giuseppe. Principii di diritto processuale civile. 3ํㅡㄹ ed. Napoli : Jovene, 1923. 
CINTRA, Antônio Carlos de Araújo. Apontamentos sobre os fatos da causa e a apelação. Meios de impugnação ao julgado civil - Estudos em homenagem a José Carlos Barbosa Moreira. Adroaldo Furtado Fabrício (coord.). Rio de Janeiro: Forense, 2007.

. Sobre os limites objetivos da apelação civil. São Paulo, 1986.

CONSOLO, Claudio. Le impugnazioni delle sentenze e dei lodi. $3^{\underline{a}}$ ed. Milano: CEDAM, versão digital, c. 1, item 2.3

COVAS, Silvano. O duplo grau de jurisdição. Aspectos polêmicos e atuais dos recursos. Eduardo Pellegrini de Arruda Alvim; Nelson Nery Jr.; Teresa Arruda Alvim (coord.). São Paulo: RT, 2000.

CUNHA, Leonardo Carneiro da. A cassação e o superior tribunal de justiça brasileiro. Revista de processo. São Paulo: RT, v. 299, jan. 2020.

DANTAS, Bruno. Comentários ao art. 939. Comentários ao Código de Processo Civil. Cassio Scarpinella Bueno (coord.). São Paulo: Saraiva, 2017.

DIDIER JR, Fredie. Pressupostos processuais e condições da ação: o juizo de admissibilidade do processo. São Paulo: Saraiva, 2005.

DIDIER JR, Fredie; CUNHA, Leonardo Carneiro da. Curso de direito processual civil. 13ª ed. Salvador: Juspodivm, 2016, v. 3.

DINAMARCO, Cândido Rangel. O efeito devolutivo da apelação e de outros recursos. Nova era do processo civil. 2a ed. São Paulo: Malheiros, 2007.

ELIAS, Carlos Eduardo Stefen. Apelação - Os limites objetivos do efeito devolutivo. São Paulo: Atlas, 2010.

FAGUNDES, Miguel Seabra. Dos recursos ordinários em matéria civil. Rio de Janeiro: Forense, 1946.

FAIRÉN GUILLÉN, Víctor. Estudios de derecho procesal. Madrid: Editorial Revista de Derecho Privado, 1955.

FARIA, Márcio Carvalho. O novo Código de Processo Civil vs. A jurisprudência defensiva. Coleção novo CPC: Doutrina Selecionada - Processo nos tribunais e meios de impugnação às decisões judiciais. Lucas Buril de Macêdo; Ravi Peixoto; Alexandre Freire (org.). 2ª ed. Salvador: Juspodivm, 2016.

FERREIRA, William Santos. Comentários ao art. 1.013. Comentários ao Código de Processo Civil. Cassio Scarpinella Bueno (coord.). São Paulo: Saraiva, 2017.

GIUDICEANDREA, Nicola. Le impugnazioni civili. Milano: Giuffrè, 1952, v. 2.

GONÇALVES, Mauro Pedroso. Recurso de apelação e novas aplicações de seu efeito devolutivo. Curitiba: Juruá, 2009.

GRANADO, Daniel Willian. Recurso de apelação no novo Código de Processo Civil, cit., p. 157 e 171

GRECO, Leonardo. Instituições de processo civil. Rio de Janeiro: Forense, 2015.

JORGE, Flávio Cheim. Teoria geral dos recursos cíveis. 7aㅡ ed. São Paulo: RT, 2015.

JORGE, Flávio Cheim; SIQUEIRA, Thiago Ferreira. A sanabilidade dos requisitos de admissibilidade dos recursos: notas sobre o art. 932, parágrafo único, do CPC/15. Coleção novo CPC: Doutrina Selecionada - Processo nos tribunais e meios de impugnação às decisões judiciais. Lucas Buril de Macêdo; Ravi Peixoto; Alexandre Freire (org.). 2a ed. Salvador: Juspodivm, 2016.

KOZIKOSKI, Sandro Marcelo. O CPC 2015 e a relativização do princípio da proibição da reformatio in pejus. Coleção novo CPC: Doutrina Selecionada - Processo nos tribunais e meios de impugnação às decisões judiciais. Lucas Buril de Macêdo; Ravi Peixoto; Alexandre Freire (org.). 2a ed. Salvador: Juspodivm, 2016.

Sistema recursal. Salvador: Juspodivm, 2016.

LASPRO, Oreste Nestor de Souza. Duplo grau de jurisdição no direito processual civil. São Paulo: RT, 1995.

LIEBMAN, Enrico Tullio. Appunti sulle impugnazioni. Milano: La Goliardica, 1959. 
LIMA, Alcides de Mendonça. Introdução aos recursos cíveis. 2ª ed. São Paulo: RT, 1976.

LIMA, Patrícia Carla de Deus. O julgamento da apelação do art. 285-A do CPC. Aspectos polêmicos e atuais dos recursos cíveis. Nelson Nery e Teresa Arruda Alvim (coord.). São Paulo: RT, 2007, v. 11.

LOPES, Bruno Vasconcelos Carrilho. A reformatio in peius no direito processual civil. In: Nelson Nery Jr. e Teresa Arruda Alvim (Coord.). Aspectos polêmicos e atuais dos recursos cíveis e de outros meios de impugnação às decisões judiciais. São Paulo: RT, 2005, v. 8.

LUISO, Francesco Paolo. Appello. Digesto delle discipline privatistiche. Torino: UTET, 1998 (reimpressão da edição de 1987).

Diritto processuale civile, II, cit., p. 396-397.

. Invalidità della sentenza e mezzi di gravame. Rivista di diritto processuale. Padova:

CEDAM, v. LXIV, n. 1, 2009, p. 27-28

MACÊDO, Lucas Buril de. Objeto dos recursos cíveis. Salvador: Juspodivm, 2019

MACÊDO, Lucas Buril de; PEIXOTO, Ravi Medeiros. Ônus da prova e sua dinamização. 2a ed. Salvador: Juspodivm, 2016

MACHADO GUIMARÃES, Luiz. Efeito devolutivo da apelação. Estudos de direito processual civil. Rio de Janeiro-São Paulo: Jurídica e Universitária, 1969.

MALLET, Estêvão. Reforma de sentença terminativa e julgamento imediato do mérito (Lei 10.352). Aspectos polêmicos e atuais dos recursos cíveis e de outros meios de impugnação às decisões judiciais.

Nelson Nery Jr. e Teresa Arruda Alvim (coord.). São Paulo: RT, 2003, v. 7.

MARANHÃO, Clayton. Da ordem dos processos nos tribunais. Aspectos polêmicos dos recursos cíveis e assuntos afins. São Paulo: RT, 2017, v. 13, p. 82-84

MARCATO, Ana Cândida Menezes. Considerações sobre o princípio processual do duplo grau. Teoria do processo - panorama doutrinário mundial. Fredie Didier Jr. (org.). Salvador: Juspodivm, 2010, v. 2 , p. 58

MARTINS, Pedro Batista. Recursos e processos de competência originária dos tribunais. Rio de Janeiro: Forense, 1957, p. 195

MEDINA, José Miguel Garcia. A recentíssima reforma do sistema recursal brasileiro - análise das principais modificações introduzidas pela Lei 10.352/2001, e outras questões. Aspectos polêmicos e atuais dos recursos e de outros meios de impugnação às decisões judiciais. São Paulo: RT, 2002, v. 6.

. Direito processual civil moderno. São Paulo: RT, 2020.

MONTEIRO, João. Teoria do processo civil. $6^{\underline{a}}$ ed. (atualizado por J M de Carvalho Santos). Rio de Janeiro: Borsoi, 1956, p. 604-605

MONTELEONE, Girolamo. Diritto processuale civile. $8^{\mathrm{a}}$ ed. Milano: CEDAM, 2018, volume II, p. 568

OLIVEIRA, Gleydson Kleber Lopes de. Apelação no direito processual civil, São Paulo: RT, 2009.

OLIVEIRA, Pedro Miranda de. Apontamentos sobre o novíssimo sistema recursal. Revista de Processo. São Paulo: RT, 2015, v. 250.

. O duplo grau de jurisdição e o julgamento imediato pelos tribunais no CPC/2015.

Aspectos polêmicos dos recursos cíveis e assuntos afins, v. 13. São Paulo: RT, 2017.

PINTO, Nelson Luiz. Manual dos recursos cíveis. São Paulo: Malheiros, 2002.

PODETTI, J. Ramiro. Tratado de los recursos. Buenos Aires: EDIAR, 1958.

PONTES DE MIRANDA, Francisco Cavalcanti. Comentários ao Código de Processo Civil. 3ª ed. Rio de Janeiro: Forense, 1999, tomo VII.

PROTO PISANI, Andrea. Lezioni di diritto processuale civile, cit., p. 503. 
QUEIROZ, Pedro Gomes de. A apelação no CPC/2015. Revista de Processo. São Paulo: RT, v. 260, 2016.

REDENTI, Enrico; VELLANI, Mario. Diritto processuale civile. Milano: Giuffrè, 2011.

REICHELT, Luis Alberto. Sistemática recursal, direito ao processo justo e o novo Código de Processo Civil: os desafios deixados pelo legislador ao intérprete. Revista de Processo. São Paulo: RT, 2015, v. 244.

RICCI, Gian Franco. Diritto processuale civile. $6^{\mathrm{a}}$ ed. Torino: Giappichelli, 2017, v. II⿳․

SÁ, Djanira Maria Radamés de. A atividade recursal civil na reforma do poder judiciário. São Paulo: Pillares, 2006.

SANTOS, Ernane Fidélis dos. Evolução legislativa do sistema recursal de primeiro grau no Código de Processo Civil brasileiro. Meios de impugnação ao julgado civil - Estudos em homenagem a José Carlos Barbosa Moreira. Adroaldo Furtado Fabrício (coord.). Rio de Janeiro: Forense, 2007.

SATTA, Salvatore. Le impugnazioni. Casa Editrice Dr. Francesco Vallardi, 1962.

SILVA, Márcio Henriques Mendes da. Tentativa de sistematização do efeito devolutivo dos recursos. Aspectos polêmicos e atuais dos recursos cíveis. Nelson Nery e Teresa Arruda Alvim (coord.). São Paulo: RT, 2007, v. 11.

SILVA, Ovídio A. Baptista da. Curso de processo civil. $7^{a \underline{a}}$ ed. Rio de Janeiro: Forense, 2006.

SIQUEIRA, Thiago Ferreira. Duplo grau de jurisdição e "teoria da causa madura" no novo Código de Processo Civil. Coleção novo CPC: Doutrina Selecionada - Processo nos tribunais e meios de impugnação às decisões judiciais. Lucas Buril de Macêdo; Ravi Peixoto; Alexandre Freire (org.). $2^{\underline{a}}$ ed. Salvador: Juspodivm, 2016.

SOUZA, Bernardo Pimentel. Introdução aos recursos cíveis e à ação rescisória. $5^{\underline{a}}$ ed. São Paulo: Saraiva, 2008.

TEODOLDI, Alberto. I motivi specifici e le nuove prove in appello dopo la novella 'iconoclastica' del 2012. Rivista di diritto processuale. Padova: CEDAM, v. LXVIII, n. 1, 2013.

L'appello civile. Torino: Giappichelli, 2016.

THEODORO JR., Humberto. Inovações da Lei 10.353/2001, em matéria de recursos cíveis e duplo grau de jurisdição. Aspectos polêmicos e atuais dos recursos e de outros meios de impugnação às decisões judiciais. São Paulo: RT, 2002, v. 6.

TONIOLO, Ernesto José. A evolução do conceito de reformatio in peius e a sua proibição no sistema recursal do processo civil. Revista de Processo. São Paulo: RT, v. 254, 2016.

TUCCI, José Rogério Cruz e. A causa petendi no processo civil. 3aㅡ ed. São Paulo: RT, 2009. . Lineamentos da nova reforma do CPC. 2ª ed. São Paulo: RT, 2002.

USTÁRROZ, Daniel; PORTO, Sergio Gilberto. Manual dos recursos cíveis. $6^{\underline{a}}$ ed. Porto Alegre: Livraria do Advogado, 2017.

VIOLIN, Jordão. Onde está a segurança jurídica? Colegialidade, polarização de grupo e integridade dos tribunais. Revista de Processo. São Paulo: RT, v. 268, 2017.

ZANZUCCHI, Marco Tullio. Nuove domande, nuove eccezioni e nuove prove in appello. Milano: Società Editrice Libraria, 1916. 